\title{
EL SOLVE ET REPETE FRENTE AL DERECHO ADMINISTRATIVO SANCIONADOR. UN EXAMEN DE LEGITIMIDAD*
}

\author{
SOLVE ET REPETE IN THE SANCTIONING ADMINISTRATIVE LAW.
}

A TEST OF LEGITIMACY

LE SOLVE ET REPETE DANS LE DROIT ADMINISTRATIF SANCTIONNER.

UN TEST DE LÉGITIMITÉ

Marcelo Araya Rojas*

\begin{abstract}
RESUMEN
En este artículo se realiza un análisis de la constitucionalidad de la institución del solve et repete en el Derecho Administrativo sancionador. El autor propone un estándar de constitucionalidad abstracto, que prescinde de la eventual pervivencia de la institución en ciertas hipótesis de inaplicabilidad. Para este efecto, analiza la sanción administrativa y su relación con el solve et repete en el marco del proceso jurisdiccional impugnatorio. Analizando la jurisprudencia del Tribunal Constitucional en diversas declaraciones de inaplicabilidad. Para, finalmente, concluir la inconstitucionalidad de esta figura y la necesidad de desterrarla del sistema jurídico.
\end{abstract}

PalabRas CLAVE: Derecho Administrativo sancionador - Solve et repete - Inconstitucionalidad

ABSTRACT

This article is an analysis of the constitutionality of the institution of solve et repete in administrative law sanctions. The author proposes an abstract constitutional standard, which dispenses with the eventual survival of the institution on certain assumptions of inapplicability. The article analyzes the administrative sanctions and its relation to solve et repere in the context of judicial proceedings. It also analyzes the Constitutional Court's jurisprudence in various declarations of inapplicability. It finally concludes the unconstitutionality of this figure and the necessity to banish it of the legal system.

KEY WORDS: Administrative sanction - Solve et repete - Unconstitutionality

RÉSUMÉ

Cet article est une analyse de la constitutionnalité de l'institution de solve et repete dans les sanctions de droit administratif. L'auteur propose un standard constitutionnelle abstraite, qui dispense de la survie éventuelle de l'institution sur certaines hypothèses d'inapplicabilité. A cet effet, il analyse la sanction administrative et sa relation avec le solve et repete dans le cadre d'une procédure judiciaire. Il analyse aussi la jurisprudence de la Cour constitutionnelle

\footnotetext{
*El artículo fue aprobado para su publicación el 15 de abril de 2013.

** Abogado. Licenciado en Ciencias Jurídicas y Sociales de la Universidad de Chile. Candidato a Magíster del Magíster en Derecho mención Derecho Público por la Universidad de Chile. Correo electrónico: marceloaraya7@gmail.com.
} 
dans diverses déclarations d'inapplicabilité. Pour finalement conclure à l'inconstitutionnalité de cette figure et la nécessité de sa interdire dans le système juridique.

MOTS CLÉS: Sanction administrative - Solve et repete - Inconstitutionnalité

\section{INTRODUCCIÓN}

El presente artículo tiene por objeto examinar la constitucionalidad de la institución del solve et repete en nuestro sistema jurídico. Se propondrá para dicho efecto un estándar de constitucionalidad abstracto, vale decir, que prescinda de la eventual pervivencia de la institución en ciertas hipótesis de aplicabilidad. Por tanto, la presente investigación tiene por objeto determinar si el instituto aludido cumple con los estándares de reproche suficientes como para proponer su expulsión definitiva del ordenamiento jurídico, respecto de todas las disposiciones que le contengan, y sean cuales sean sus requisitos exigidos en cuanto presupuesto de procesabilidad. Para dicho efecto, se comenzará introduciendo al lector en la temática abordada, analizando la sanción administrativa y su relación con el solve et repete en el marco de un proceso jurisdiccional impugnatorio; luego, se expondrán los argumentos que darían lugar a sostener la legitimidad de la figura, sobre la base de opiniones doctrinales (las que, como oportunamente prevendremos, no necesariamente se inscriben en su defensa), y ciertas posiciones que sobre el particular ha propuesto nuestro Tribunal Constitucional; en seguida se analizará la jurisprudencia sentada al respecto por el Tribunal, en diversas declaraciones de inaplicabilidad y, principalmente, en la STC Rol No 1345-2009, de 25 de mayo de 2009, referida a la inconstitucionalidad del artículo 171 inciso $1^{\circ}$ frase final del Código Sanitario; finalmente, al cierre de la investigación, se intentará sentar, a la luz de lo expuesto y de manera propositiva, un principio general referido a la necesidad de desterrar definitivamente la figura del solve et repete de nuestro sistema jurídico.

\section{LA SANCIÓN ADMINISTRATIVA EN CUANTO PRESUPUESTO}

\section{DE IMPUGNABILIDAD JUDICIAL}

Al comenzar este estudio cabe precisar la noción de sanción administrativa, la cual, en el contexto del control ejercido por la Administración sobre los actos de los particulares ${ }^{1}$, debe ser entendida -para los efectos que nos interesan-como el

\footnotetext{
${ }^{1} \mathrm{Al}$ respecto, CORDERO explica que: "El control consta en un juicio de conformidad a ciertas reglas, que implica, en caso de disconformidad, una medida represiva, preventiva o rectificadora (...). Por lo dicho, resulta evidente que el control no es propiamente un acto, sino que el desarrollo lógico de una actividad comprobadora, por lo que requiere necesariamente de parámetros previos (jurídicos, contables, fines desarrollados a través de programas o planificaciones) y que al término de su fase activa envuelve un juicio de valoración, que como se dijo pueden importar la adopción de medidas de distinta significación, dependiendo si hubo conformidad o disconformidad con el término de comparación efectuada, lo que le resta conceptualmente la idea de autonomía”. (CORDERO VEGA, Luis (2009). El control de la administración del Estado. Santiago: Editorial LegalPublishing, p. 20).
} 
presupuesto de la impugnación judicial en cuyo marco se inscribirá la institución del solve et repete. Pues bien, ésta es conceptualizada de manera relativamente pacífica por algunos autores. Así, GARCÍA DE ENTERRía la define como "un mal inflingido por la Administración al administrado como consecuencia de una conducta ilegal". A su vez, Bermejo Vera como "una resolución administrativa de gravamen que disminuye o debilita -incluso elimina- algún espacio de la esfera jurídica de los particulares, bien porque se le priva de un derecho, bien porque se le impone un deber u obligación, siempre como consecuencia de la generación de una responsabilidad derivada de la actitud de los mismos". A su turno, para GAMERO CASADO ésta consiste en "la privación, restricción o suspensión de determinados derechos o bienes jurídicos del sujeto responsable de la infracción, precisamente como reacción -castigo- a la comisión de la misma”. De lo expuesto, la doctrina extrae tres elementos comunes a la sanción administrativa, cuales son: a) la carga que se le impone al individuo; b) el gravamen que debe ser consecuencia de una conducta lesiva a un bien jurídico protegido en una infracción administrativa, y c) el poder que ostenta la autoridad administrativa para imponerla, de acuerdo con las normas y principios que rigen la actividad sancionadora. Junto con ello, la sanción administrativa exige, en cuanto manifestación del ius puniendi estatal, la verificación de ciertos principios: el principio de legalidad, en sus dos vertientes: tipicidad y reserva de ley, culpabilidad, proporcionalidad, interdicción de la analogía, non bis in idem, entre otros ${ }^{2}$. Luego, no toda figura que involucre resultados no deseados para el sujeto fiscalizado importará el curso de una "sanción administrativa", sólo será tal en el evento que aquélla cumpla con los cánones recién reseñados ${ }^{3}$.

Entre nosotros, en cambio, RoMÁn sostiene que la sanción administrativa es un concepto jurídico indeterminado, por lo que todo intento por definirla es vano y a su vez peligroso, pues con ello se corre el riesgo de rigidizar en demasía su concepto, correspondiendo en consecuencia a la jurisprudencia determinar su ocurrencia en cada caso concreto y a la doctrina, a lo sumo, fijar sus lineamientos generales (previniendo, en todos los casos, una indeseada "hiperinflación" del concepto $)^{4}$. Para este último efecto, el autor sostiene la existencia conjunta de

${ }^{2}$ Ramírez Torrado, María Lourdes (2007). "La sanción administrativa y su diferencia con otras medidas que imponen cargas a los administrados en el contexto español". Revista de Derecho, No 27, Barranquilla. Disponible en: <http://redalyc.uaemex.mx/pdf/851/85102711.pdf> [Consulta: 5 enero 2011], pp. 272292.

${ }^{3}$ Así lo hemos expuesto en investigaciones anteriores, haciendo un claro distingo entre la noción de sanción administrativa y aquella que hemos denominado simplemente reproche. $\mathrm{Al}$ respecto, sugiero consultar mi artículo titulado El reproche administrativo y su eficacia regulatoria en el marco de las potestades de fiscalización ejercidas por la Contraloría general de la República (Universidad de Chile, Santiago, 2010).

${ }^{4}$ En efecto, el profesor Román enseña que la discusión que ha habido en torno al Derecho Administrativo sancionador, en específico sobre los principios que lo informan, ha partido del supuesto -no reconocido expresamente- de que cualquier actuación lesiva desplegada por la Administración importa una "sanción administrativa", produciendo con ello una hiperinflación del concepto, y una ampliación desmedida de la órbita de acción de los principios del Derecho Administrativo sancionador, que es preciso corregir. (Román 
cuatro elementos que dan lugar en forma indubitada a la comprensión del núcleo esencial de toda sanción administrativa: a) su imposición por parte de un órgano administrativo; b) la lesión o menoscabo de derechos del administrado ${ }^{5}$, o la imposición de un deber para éste; c) su establecimiento por el ordenamiento jurídico como reacción a su contravención, y d) su finalidad de represión o castigo del ilícito administrativo ${ }^{6}$.

Ahora bien, las sanciones administrativas pueden revestir diversas formas según el tipo de estatuto e ilícito de que se trate (sanciones disciplinarias, decomiso de artículos, revocación de licencias, suspensión de la actividad, clausura, multa, etc.). Debemos precisar, al respecto, que sólo la sanción administrativa de carácter pecuniario (multa) es susceptible de ser impugnada en sede jurisdiccional, con la limitación o requisito (según se pretenda argumentar) de la consignación previa de un porcentaje o el total de la misma, constitutiva del mecanismo del solve et repete.

\section{El solve ET REPETE. CONCEPTO}

El denominado solve et repete (literalmente "paga y repite") se encuentra consagrado, en nuestro sistema, en múltiples cuerpos normativos (todos con rango de ley), entre otros: el artículo 165 No 5 del Código Tributario ${ }^{7}$; artículo 30 de

Cordero, Cristián (2010). "El castigo en el derecho administrativo". Revista de Derecho y Humanidades, No 16, Vol. 1, p. 167).

${ }^{5}$ Resulta interesantísimo el reconocimiento expreso de dicho carácter, por cuanto es precisamente aquél el que da lugar a la revisión judicial de la sanción impuesta en el ejercicio de la potestad sancionatoria de la Administración. Dicha noción, en mi opinión, es suficiente para descartar el arrogamiento, sostenido por algunos autores, de facultades jurisdiccionales por parte de la Administración en esta materia (esto, por cuanto el mencionado carácter reconoce el menoscabo o lesión de un derecho por parte del órgano sancionador, descartándose de plano, así, la noción heterocompositiva que supone el ejercicio jurisdiccional -volveremos sobre este punto infra-). En relación con la postura que sostiene la arrogación referida, conviene consultar la obra de los profesores Iván Aróstica Maldonado y Eduardo Soto Kloss, Aróstica Maldonado, Iván (1987). "Algunos problemas de Derecho Administrativo Penal". Revista de Derecho, Universidad de Concepción, No 182; Sото KLoss, Eduardo (1979/1980). "Derecho Administrativo Penal. Notas para el estudio de la potestad sancionatoria de la Administración”. En: Boletín de Investigaciones, Facultad de Derecho, Pontificia Universidad Católica de Chile, No 44/45; Soto Kloss, Eduardo (2005). "La potestad sancionadora de la Administración, ¿se adecua a la Constitución?”. En: Sanciones Administrativas y Derechos Fundamentales, Regulación y Nuevo intervencionismo, Conferencias Santo Tomás de Aquino, Santiago.

${ }^{6}$ Román Cordero, Cristián (2009). "El debido procedimiento administrativo sancionador". Revista de Derecho Público, No 71, pp. 194-195.

${ }^{7}$ Artículo 165 No 5 del Código Tributario: “El Director Regional resolverá el reclamo dentro del quinto día desde que los autos queden en estado de sentencia y, en contra de ésta, sólo procederá el recurso de apelación para ante la Corte de Apelaciones respectiva, el que se concederá en ambos efectos. Dicho recurso deberá entablarse dentro de décimo día, contado desde la notificación personal o por cédula de dicha resolución. Sólo podrá concederse la apelación previa consignación por el recurrente en un Banco a la orden del Tesorero General de la República, de una cantidad igual al veinte por ciento de la multa aplicada, con un máximo de 10 Unidades Tributarias Mensuales". 
la Ley Orgánica de la Superintendencia de Valores y Seguros ${ }^{8}$, y el artículo 474 inciso $3^{\circ}$ del Código del Trabajo". Ha sido definido como "aquella institución en que el afectado por un acto sancionador dictado por la Administración, que le impone una multa, debe pagarla (sea íntegramente, sea una parte o porcentaje de ella), para poder reclamar de su juridicidad" 10 .

En concepto crítico de SоTO KLoss, en virtud del solve et repete "se ejecuta la sanción antes de que pueda ser reclamada o impugnada, y más encima se le exige el cumplimiento de ella para que (el afectado) pueda acceder a la Justicia y plantear su reclamación" ${ }^{11}$, sostiene dicho autor además que el solve et repete constituye una violación grave en los derechos de las personas, específicamente al artículo 19 No 3 inciso $5^{\circ}$ de la Constitución Política de la República. El citado académico asimismo argumenta -sobre la base de la teoría de los derechos fundamentales- que aun cuando sea la ley el instrumento que impone la obligación en estudio, la noción de debido proceso no tolera la "autotutela ejecutiva" de los actos administrativos (llegando a asimilarlos para estos efectos a los actos privados) ${ }^{12}$, señalando finalmente que todo acto que lesione el derecho de un particular puede ser reclamado libremente por éste, sin que valga impedimento alguno a su ejercicio del derecho a la acción ${ }^{13}$.

\section{Argumentos en favor de la legitimidad de la institución}

En el presente capítulo haremos notar los argumentos que tradicionalmente se esgrimen en favor de la figura que analizamos, tanto desde la dogmática administrativa como desde la jurisprudencia del Tribunal Constitucional. He de prevenir, en lo que respecta al primer grupo, que en ausencia de un desarrollo doctrinal suficientemente acabado en la materia, presentaré, junto a las posiciones clásicas en

\footnotetext{
${ }^{8}$ Artículo 30 de la Ley Orgánica de la Superintendencia de Valores y Seguros: "El afectado podrá reclamar de la aplicación de la multa o de su monto ante el juez de letras en lo civil que corresponda, dentro del plazo de diez días de indicado en el inciso anterior, previa consignación del $25 \%$ del monto total de la multa, en la Tesorería General de la República. La consignación no podrá ser superior al equivalente a 500 unidades de fomento o a 1.000 unidades de fomento".

${ }^{9}$ El Código del Trabajo, vigente hasta el 31 de agosto de 2009 en Santiago, en su artículo 474 inciso $3{ }^{\circ}$ señalaba: "La resolución que aplique la multa administrativa será reclamable ante el Juez de Letras del Trabajo, dentro de quince días de notificada por un funcionario de la Dirección del Trabajo o de Carabineros de Chile, previa consignación de la tercera parte de la multa".

${ }^{10}$ Sото KLoss, Eduardo (2009). "Solve et repete. Notas sobre un resabio absolutista en el Estado Constitucional de Derecho”. En: Derecho Administrativo. Temas Fundamentales, Santiago: LegalPublishing.

${ }^{11}$ Ídem.

${ }^{12} \mathrm{Hacia}$ el final de la presente investigación, haremos notar que el camino propuesto por el profesor Soto Kloss en este punto, para fundar la ilegitimidad del solve et repete (no obstante compartir dicho juicio) no es el más adecuado.

13 "Y es que en Chile, y de acuerdo con la Constitución, ningún órgano del Estado detenta poderes absolutos, ninguno es soberano, ninguno está dotado de poderes ilimitados" (SоTо KLOss (2009), p. 526).
} 
la materia, otras que podrían, asimismo, plantearse con cierta sensatez, tomando en cuenta ciertos tópicos atinentes a la teoría del Derecho Administrativo Sancionador (sin perjuicio que sus exponentes no hayan de inscribirse necesariamente en la defensa de la institución).

\subsection{Desde la dogmática}

\subsubsection{La ejecutividad y ejecutoriedad del acto administrativo}

Sabemos que uno de los privilegios emblemáticos de la Administración del Estado, en el ejercicio de sus potestades sancionatorias, es la posibilidad de ejecución inmediata y directa de lo resuelto en el acto administrativo respectivo, sin necesidad de un procedimiento jurisdiccional declarativo que imponga la obligación de su cumplimiento. En concepto de García de EnTERría y FernándeZ, se reconoce a la Administración del Estado por esta vía, una potestad de autotutela declarativa y ejecutiva que le permite dotar a sus actos de una potencia y eficacia excepcionales dentro del orden jurídico, sin perjuicio de las facultades de revisión que ostentan los tribunales de justicia ${ }^{14}$.

Esta eficacia tiene su fundamento en la presunción de legalidad o validez que tendrían estos actos y puede implicar, como explica FERRADA, su obligatoriedad jurídica (ejecutividad) y su potencialidad de ejecución coactiva (ejecutoriedad). Como señala, asimismo, este autor, esto es lo que pareciera reconocer expresamente la Ley No 19.880, sobre Bases de los Procedimientos Administrativos, al establecer en su artículo $3^{\circ}$ que "los actos administrativos gozan de una presunción de legalidad, de imperio y exigibilidad frente a sus destinatarios, desde su entrada en vigencia, autorizando su ejecución de oficio por la autoridad administrativa...", para luego añadir en el artículo 51, relativo a la ejecutoriedad, que "los actos de la Administración Pública sujetos al Derecho Administrativo causan inmediata ejecutoria...”. Así es evidente que la fuerza ejecutiva de la actividad administrativa deriva del propio órgano emisor del acto, en la medida que cumpla con los requisitos de existencia establecidos en el mismo artículo $3^{15}$.

Por tanto, de las normas citadas se colige que los actos emanados de los órganos de la Administración del Estado gozan de los privilegios de ejecutividad y ejecutoriedad, lo que les permite su ejecución inmediata sin intervención de los tribunales de justicia, sería dable sostener prima facie la legitimidad de la consignación de la totalidad o un porcentaje de la sanción pecuniaria, en atención a que dicha obligación no sería sino una manifestación más del revestimiento que el

\footnotetext{
${ }^{14}$ García de Enterría, Eduardo y Fernández, Tomás Ramón (1996). Curso de Derecho Administrativo. T. I, Madrid: Editorial Civitas, pp. 491 y ss.

${ }^{15}$ Ferrada Bórquez, Juan Carlos (2007). "Las potestades y privilegios de la Administración Pública en el régimen administrativo chileno". Revista de Derecho (Valdivia), Vol. XX, No 2, p. 83.
} 
ordenamiento jurídico ha querido otorgarle a la sanción administrativa, a efectos de su pronta materialización. En suma, el solve et repete constituiría, en concepto de esta doctrina, un efecto reflejo del principio de ejecutividad ${ }^{16-17}$.

Expondremos al final de esta investigación cómo este argumento, lejos de constituirse en estandarte teórico de la posición legitimadora del solve et repete, es clave para proponer su erradicación. Por ahora analicemos otros.

\subsubsection{La protección de bienes jurídicos de carácter colectivo}

Este argumento se encuentra estrechamente ligado a la noción tutelar del Derecho Administrativo (y, en específico, del procedimiento administrativo) respecto del interés público ${ }^{18}$. En efecto, ha de estimarse (y así lo han hecho sistemáticamente los servicios públicos al actuar como parte en los procesos constitucionales de inaplicabilidad o inconstitucionalidad) que así como puede considerarse que la regla del solve et repete constituye, eventualmente, una limitación del derecho de acceso a la justicia, no puede desconocerse que ésta resguarda bienes jurídicos constitucionales concernientes a la comunidad toda, como el derecho a la vida, a la salud de la población, o la integridad física y psíquica de las personas, lo que daría lugar a sostener, en todas sus hipótesis de aplicación, su viabilidad y legitimidad.

\footnotetext{
${ }^{16}$ Como explica Martín Oviedo, esta doctrina fue recogida en su oportunidad por la doctrina del Consejo de Estado español, en el dictamen No 5.127, de 14 de diciembre de 1949, en los siguientes términos: "Positivamente, tal doctrina (la del "privilegio de la decisión ejecutoria" -equivalente al principio de ejecutividad-) encuentra cumplida justificación en los textos legales que normalmente la enuncian de modo casuistico, afirmando, por una parte, la ejecutoriedad de los actos administrativos y, por otra, explicando el alcance de esta ejecutoriedad según el principio del solve et repete". (Texto citado en MARTín OvIEDO, José María (1969). "La decadencia de la regla 'solve et repete' y la doctrina del Consejo de Estado". Revista de Administración Pública, Madrid, № 20, pp. 162-163).

${ }^{17}$ Este argumento presenta inmediatamente dos objeciones. A saber: a) La vinculación negativa, en cuanto ámbito de aplicación del principio de legalidad (en cuya virtud la Administración no puede actuar sino amparándose en la ley, la cual constituye el límite externo de su actuación), dado que la ley no consagra expresamente al solve et repete como medio compulsivo, respecto de la sanción cursada; b) por otro lado, conforme explica FERRADA (2007), sin perjuicio de la ejecutividad y ejecutoriedad vigente, nuestro ordenamiento jurídico no revistió a la Administración del Estado -como sí ocurre en el modelo español de nuestra Ley de Bases de los Procedimientos Administrativos- de "medios de ejecución forzosa directa", a efectos de obtener el cumplimiento forzado de sus resoluciones, restando para dicho fin sólo la vía compulsiva ordinaria (jurisdiccional).

18 "De este modo, es necesario considerar al procedimiento administrativo como la sede en que el interés público abstracto previsto por la ley pasará a especificarse, por medio de una composición de los intereses involucrados, en el interés público concreto que habrá de informar la decisión finalmente adoptada" (Cordero Vega, Luis (2005). "Entre la deferencia, los estándares de control judicial y los procedimientos administrativos. Comentarios a las sentencias sobre el caso Celco". Revista de Derecho Público, No 67, pp. 450-451).
} 
A lo expuesto, podría agregarse que -como expresa Román- no es posible dejar de señalar que hoy se evidencia la conformación de una nueva sociedad en la que distintos actores, con su acción u omisión, crean relevantes riesgos en los ámbitos especializados en los que se desenvuelven, que pueden derivar en importantes daños para las personas o cosas -incluso mayores que los que amenaza, con su actuación, la misma Administración-. Es por ello que hoy, para atender este nuevo orden de cosas, no puede seguir siendo el fin y objeto de los instrumentos del Derecho Público formular imperativos sólo a los órganos del Estado, sino que también a los particulares, en especial aquellos que, de hecho o de derecho en este nuevo escenario, detentan formidables poderes en el seno social $^{19}$.

La jurisprudencia de nuestro Tribunal Constitucional respecto de este argumento no ha sido, lamentablemente, uniforme, ya que si bien lo aceptó en una oportunidad -en el considerando duodécimo de la STC Rol No 1173-2009, en cuestión de inconstitucionalidad planteada sobre el hoy derogado artículo 474 inciso tercero del Código del Trabajo ${ }^{20-21}$, ya analizaremos infra (capítulo III del presente estudio) cómo el Tribunal, luego, se hace cargo del mismo desestimándolo, al efectuar el test de proporcionalidad (entre las garantías constitucionales conculcadas) en el razonamiento de la sentencia de inconstitucionalidad Rol No 1345-2009, referida al solve et repete en materia sanitaria.

\subsubsection{La garantía de seriedad del solve et repete y la noción de consignación}

Se ha expuesto (en juicio, conforme ejemplificaré más adelante) acerca del rol que le cabría a la regla en estudio en relación con el desincentivo de la litigación frívola o con fines puramente dilatorios. Así, en virtud del solve et repete se evitaría la interposición de reclamos infundados en contra de sanciones administrativas correctamente impuestas, blindando así al sistema judicial de un superávit innecesario de litigios en materia contenciosa administrativa (tal sería el fin regulatorio de la regla en estudio, el cual daría -conforme a dicha óptica- lugar a su legitimidad). Veremos próximamente cómo el Tribunal Constitucional rebate, en sólidos términos, dicho argumento en el considerando decimotercero de la STC Rol No 1345-2009.

\footnotetext{
${ }^{19}$ RomÁn (2009), p. 187.

20 "Que, asimismo, no debe dejar de recordarse que, en la especie, las multas a que se refiere el precepto que se impugna se imponen por medio de un acto administrativo, en ejercicio de potestades sancionatorias por violación a normas que establecen derechos de carácter irrenunciable a favor del trabajador, en el marco de una relación laboral, en la cual uno de sus elementos es la desigualdad de las partes, lo que es suplido por la legislación laboral cuya eficacia se asegura por la aplicación de multas". (Opinión de los Ministros señores Juan Colombo Campbell, Hernán Vodanovic Schnake, Enrique Navarro Beltrán y Francisco Fernández Fredes).

${ }^{21}$ Volveremos sobre esta sentencia infra 3.2.2.
} 
Por otro lado, se estima que la figura no guarda relación sustancial alguna con la sanción administrativa cuya imposición se impugna en sede jurisdiccional, es decir, el solve et repete no importa el cumplimiento (total o parcial) de la sanción pecuniaria impugnada, sino una mera consignación requerida en cuanto presupuesto de procesabilidad de la acción respectiva ${ }^{22}$, o dicho de otro modo, una suma de dinero establecida por la ley (sólo) como un requisito habilitante para entrar en juicio $^{23}$.

\subsubsection{El procedimiento administrativo como estadio heterocompositivo suficiente y la deferencia judicial}

Este argumento apunta a la fuerza heterocompositiva suficiente de la cual gozaría el procedimiento administrativo sancionador frente al proceso jurisdiccional, en cuanto medio de solución de conflictos entre privados y los propios órganos de la Administración, llegando a erigir a aquél-siguiendo la terminología de Carnelutti- en un verdadero "equivalente jurisdiccional", lo que daría lugar, desde luego, a la imposición legítima de gravámenes ante el ejercicio de (innecesarias) reclamaciones ulteriores, respecto de lo allí resuelto. Al respecto, GONZÁLEZ Pérez destaca -llegando al extremo señalado- las virtudes del procedimiento administrativo en cuanto instrumento de evitación del proceso, señalando que "una correcta regulación de los cauces formales de la actuación administrativa, la intervención en el procedimiento administrativo de órganos cualificados, y la posibilidad de someter la decisión de los litigios con una Administración Pública a órganos no sujetos a instrucciones jerárquicas, podrían permitir la satisfacción de las pretensiones en vía administrativa, evitando al ciudadano la necesidad de tener que poner en marcha el complicado, costoso y, por mucho que se agilice, lento mecanismo procesal" 24 .

La noción de suficiencia esgrimida podría, asimismo, reforzarse ante la exigencia de procedimientos administrativos cada vez más garantes del debido proceso (en los términos de "justo y racional procedimiento" concebidos en el artículo 19 No 3 inciso quinto de la Constitución Política de la República),

\footnotetext{
${ }^{22}$ Así, adoptando una posición iusprocesalista, se ha calificado al solve et repete como presupuesto procesal (Giannini), como excepción (Chiovenda), o como obstáculo al libre ejercicio del derecho a recurrir (jurisprudencia del Tribunal Supremo español). MarTín Oviedo (1969), p. 152.

${ }^{23}$ En estos términos planteó su argumentación, en este punto, el Instituto de Salud Pública, en el proceso de inconstitucionalidad respecto del artículo 171 inciso primero, frase final, del Código Sanitario. (Véase STC Rol No 1345, 25 de mayo de 2009).

${ }^{24}$ GonzÁlez Pérez, J. (1998). "Procedimiento administrativo y proceso administrativo. (Ante la modificación de la ley No 30/1992, de 26 de noviembre (RCL, 1992, 2512, 2775 y RCL, 1993, 246)”. REDA, No 9, p. 325. Citado por CoRdero (2009), p. 157.
} 
condición de importante raigambre a nivel doctrinario ${ }^{25}$ y jurisprudencial ${ }^{26}$, no obstante no ser la misma necesariamente absorbida, tal como explica ROMÁN, por la supletoriedad de la Ley No 19.880 , respecto de los procedimientos administrativos sancionadores ${ }^{27-28}$.

\begin{abstract}
${ }^{25}$ Junto con la obra citada del profesor Román (2009), resulta conveniente consultar el trabajo de IzU Belloso al respecto, en España. (Izu Belloso, Miguel José (1993). "Las garantías del procedimiento administrativo sancionador: Reflexiones sobre los órganos instructores, en la protección jurídica del ciudadano: (procedimiento administrativo y garantía jurisdiccional)". En: Estudios en homenaje al profesor Jesús González Pérez, Martín-Retortillo Baquer, Lorenzo (Coord.). Vol. 1, pp. 869-888. Disponible en: <http://webs.ono. com/mizubel/garantias.pdf.> [Consulta: 4 enero 2011]). En este mismo sentido, Bordalí Salamanca, Andrés y Ferrada Bórquez, Juan Carlos (2009). Estudios de Justicia Administrativa. Santiago: Editorial LegalPublishing, pp. 131-132.

${ }^{26}$ En efecto, el Tribunal Constitucional ya en el año 1986 se pronunciaba sobre la necesidad de materializar la noción de debido proceso en el procedimiento administrativo: En STC Rol No 38-1986, 8 de septiembre de 1986 (sobre control de constitucionalidad respecto del proyecto de ley orgánica constitucional sobre sistema de inscripciones electorales y servicio electoral), señaló en sus considerandos $23^{\circ}$ y $24^{\circ}$ lo siguiente: " $23^{\circ}$ Que el artículo $19 N^{\circ} 3$ de la Constitución asegura a todas las personas: 'La igual protección de la ley en el ejercicio de sus derechos'. Luego, en los párrafos siguientes, concreta esta norma disponiendo en el inciso $5^{\circ}$ que: 'Toda sentencia de un órgano que ejerza jurisdicción deberá fundarse en un proceso previo legalmente tramitado. Corresponderá al legislador establecer siempre garantías de un racional y justo procedimiento'. $24^{\circ}$ Que examinada la citada parte de la letra h del articulo 53, a la luz de las disposiciones constitucionales transcritas en el considerando anterior, debe concluirse que ella vulnera los incisos $1^{\circ}$ y $5^{\circ}$ del $N^{\circ} 3$ del artículo 19 de la Carta Fundamental, porque no establece normas que le aseguren a quién resulte afectado por la resolución del Director del Servicio Electoral un justo y racional procedimiento ya que no contempla, entre otras garantías, ni el emplazamiento a la persona respectiva, ni la oportunidad para defenderse ni tampoco la posibilidad de deducir recurso alguno ante otra autoridad para reclamar de una eventual cancelación indebida". En este mismo sentido se pronuncia STC Rol No 43-1987, 24 de febrero de1987, en su considerando $61^{\circ}$.
\end{abstract}

${ }^{27}$ El profesor Román sostiene que es un equívoco sostener que la aplicación supletoria de la Ley No 19.880 , sobre Bases de los Procedimientos Administrativos, a los procedimientos administrativos sancionatorios (esto en ausencia de una Ley de Bases de los Procedimientos Administrativos Sancionatorios -el proyecto de dicha ley, como sabemos, fue retirado de la discusión legislativa-), da plena satisfacción a la garantía constitucional del justo y racional procedimiento, pues si bien respecto de dichos procedimientos la Ley No 19.880 efectivamente tiene aplicación supletoria, no puede entenderse que con sólo esa circunstancia se satisfaga el mandato constitucional del debido proceso, pues para ello se requiere un plus que representan las garantías propias del procedimiento penal transplantadas -siempre de forma aminorada- al procedimiento administrativo sancionador, que no consulta o bien no con la intensidad suficiente para dar cumplimiento a tal mandato, el procedimiento administrativo común. RomÁn (2009), p. 199.

${ }^{28}$ Es el criterio que ha imperado en las decisiones de mayoría del Tribunal Constitucional, en las cuestiones de inaplicabilidad derivadas de la impugnación del artículo 1o de la Ley No 19.989 (que autoriza a la Tesorería General de la República a retener de la devolución anual de impuesto a la renta, los montos adeudados del crédito solidario universitario regulado en la Ley No 19.287). En efecto, se ha declarado inaplicable tal precepto en razón de: "Que, de acuerdo al tenor literal del artículo $1^{\circ}$ de la Ley No 19.989 y a la aplicación que se le ha dado en el caso que nos ocupa, resulta que la Tesorería General de la República ejerce la facultad de retener de la devolución anual de impuestos que corresponde a los contribuyentes que aparecen como deudores de crédito universitario los montos de dicho crédito que se encontraren impagos, con la sola información que le proporciona el Administrador del Fondo Solidario de Crédito Universitario respectivo, sin dar oportunidad al aparente deudor a presentar otro descargo que no sea el certificado de pago emitido por dicho Administrador. Tal forma de actuar de un servicio público no satisface, indudablemente, las exigencias minimas de un racional y justo procedimiento, porque no permite a quien aparece como deudor de acuerdo con la información proporcionada por el Administrador del Fondo Solidario de Crédito Universitario, ejercitar ni ante la Tesorería ni ante un tribunal de justicia otro medio de defensa que no sea la prueba del pago de la obligación y siempre que 
Junto con ello, podría argüirse que el impedimento que importa el solve et repete responde al denominado principio de deferencia entre los poderes públicos, en cuya virtud se busca preservar la distinción funcional entre los órganos de la Administración y el Poder Judicial, en orden a lograr el cumplimiento óptimo de los cometidos materiales (distintos) de ambos, que exigen métodos organizativos y procedimentales diferentes, adaptados a cada esfera. En razón de este principio, los poderes públicos se deben, por una parte, una actitud permanente y recíproca de respeto y cortesía, mientras que por otra, reconocimiento y respeto de las respectivas esferas de competencia en que cada uno tiene derecho a tomar decisiones con relativa autonomía ${ }^{29}$. Por tanto, sería dable considerar -en razón de la lectura esbozada para este argumento- que el Poder Judicial tendría un deber negativo de conducta respecto de la actividad sancionatoria de la administración, en cuanto esfera funcional autónoma -esta última- de decisión.

Sin perjuicio que el argumento recién expuesto podría ser válidamente sostenido por los defensores de la institución objeto de este estudio, cabe precisar que éste adolece -a mi juicio- de un importante vicio conceptual, referido al desconocimiento de la diferencia entre los intereses jurídicos tutelados en una y otra sede. Como explica CORDERO, "la relación entre el procedimiento administrativo y el proceso judicial está dominada por dos ideas contrapuestas: la separación que existe entre estas dos clases de procedimiento y la relación funcional entre ellos. De acuerdo al principio de separación, ambos procedimientos son diferentes en cuanto a sus funciones, al papel que desempeñan las partes y la regulación jurídica, pero sobre

conste en un certificado emitido por el mismo ente cuya información es título suficiente para retener los fondos de la devolución anual de impuestos.

Una restricción tan drástica de los medios de defensa de una persona no tiene sustento racional, pues, aun cuando existen fundamentos objetivos para un cobro expedito de las deudas provenientes de los Fondos de Crédito Universitario, lo que justifica la restricción de las excepciones de que pueda valerse quien aparezca como deudor, ello no puede llegar hasta privar, en la práctica, del derecho que tiene toda persona a una defensa oportuna, sea ante el órgano administrativo que decide la retención o ante algún tribunal al que pudiera reclamarse, que en el caso de autos no existe" (STC Rol No 1449-2009, 9 diciembre 2010, Considerando $8^{\circ}$ ). En el mismo sentido: STC Rol No 1486-2009, 2 noviembre 2010, Considerando $8^{\circ}$; STC Rol No 1438-2009, 7 septiembre 2010, Considerando $8^{\circ}$; Rol No 1437-2009, 7 de septiembre de 2010, Considerando $8^{\circ}$; Rol No 1411-2009, 7 de septiembre de 2010, Considerando $8^{\circ}$. En sentido diverso a lo sostenido por el profesor Román (nota 25), y a los razonamientos aquí reproducidos, aparecen las opiniones de la disidencia de los respectivos fallos (con excepción de la STC Rol No 1486-09, en que por no haberse alcanzado la mayoría necesaria se tuvo por rechazado el requerimiento), formuladas -en todos los casos- por los Ministros señores Carmona y Fernández, y en la mayoría de ellos, por los señores Viera-Gallo, Colombo, Cea y doña Marisol Peña, en que se sostiene que "La citada Ley $N^{o} 19.880$ establece un verdadero 'debido proceso administrativo', en ejecución del mandato del artículo $63 N^{o} 18$ de la Constitución. En efecto, se trata de una ley que permite oportuna y eficazmente presentar sus alegatos y discutir las afirmaciones hechas por la Administración (articulos 10, 17 y 20), presentar prueba e impugnarla (artículos 35 y 36), que su caso sea resuelto objetivamente (artículos 11 y 12), conocer en plazo oportuno de una resolución final (artículos $7^{\circ}, 8^{\circ}, 9^{\circ}, 13,16,18,24,27,41,64$ y 65) y, en su caso, impugnarla (artículos 15, 59 y 60)". (STC Rol No 1449-2009, 9 de diciembre de 2010, Considerando $25^{\circ}$ ). En el mismo sentido: STC Rol No 1438-2009, Considerando 19º ;TC Rol oo $1437-$ 2009, Considerando $19^{\circ}$; STC Rol No 1411-2009, Considerando $19^{\circ}$.

${ }^{29}$ Cordero (2005), p. 52. 
todo por lo que respecta a la posición del sujeto responsable del procedimiento: en el procedimiento administrativo, la Administración está siempre vinculada a los intereses públicos (al interés público sectorial de que se trate en cada caso) y nunca es neutral, ni siquiera en los procedimientos en los que se enfrentan una pluralidad de intereses privados, y le corresponde en cierto modo una función de resolución de conflicto. En cambio, el Tribunal sólo debe perseguir la tutela del ordenamiento jurídico vinculada a la lesión del derecho. Incluso cuando su función se reduce a un control objetivo de la acción administrativa, no le corresponde lograr la satisfacción del interés público sectorial de que se trate en cada caso. La acción administrativa y su control se mueven en planos diferentes y tienen perspectivas que no deben confundirse" 30 .

Lo expuesto arroja como consecuencia que el acto administrativo sancionador pueda y deba ser objeto de revisión judicial (descartándose así la noción de deferencia), constituyéndose como arbitraria, luego, toda limitación al ejercicio de la respectiva acción.

\subsection{Desde la doctrina del Tribunal Constitucional}

\subsubsection{El solve et repete y su carácter de lex ordenatoria litis}

Este argumento tiene su fuente en la sostenida opinión del Ministro señor FERNÁNDEZ FREDES (y compartida en su oportunidad por el Abogado Integrante don Francisco Zúñiga Urbina ${ }^{31}$ ), en diversos votos de minoría recaídos en cuestiones de inaplicabilidad del solve et repete ${ }^{32}$. En virtud de dicha posición, el Tribunal Constitucional carecería de facultades para declarar la inaplicabilidad del solve et repete en una gestión judicial, por cuanto dicha declaración sólo podría recaer sobre normas directamente incidentes en la decisión del juez del fondo (es decir, en normas decisoria litis), y no en aquellas relativas a la prueba (probatoria litis) o a la sustanciación de la cuestión controvertida (normas ordenatoria litis -grupo en el cual se inscribe el solve et repete-), correspondiendo el conocimiento de estas últimas a los tribunales ordinarios, por la vía de la acción de protección.

$\mathrm{Al}$ respecto, los votos minoritarios aludidos esgrimen lo siguiente:

a) La gestión pendiente ante el juez del fondo se contrae exclusivamente a determinar si la sanción administrativa impuesta por el órgano administrativo respectivo fue o no correctamente aplicada conforme a derecho, motivo por el cual el precepto legal que se objeta en virtud de la acción de inaplicabilidad -aquel que

\footnotetext{
${ }^{30}$ Ibíd., p. 451.

${ }^{31}$ El distinguido profesor Zúñiga concurre al voto minoritario del Ministro Fernández Fredes en STC Rol No 792-2007, 3 de enero de 2008.

${ }^{32}$ Así, STC Roles Nos. 792-2007, 3 de enero de 2008; 946-2007, 1 de julio de 2008; 968-2008, 10 de julio de 2008; 1046-2008, 22 de julio de 2008; 1061-2008, 28 de agosto de 2008, y 1253-2008, 27 de enero de 2009.
} 
impone la consignación previa de un porcentaje o el total de la multa a impugnares claramente una norma ordenatoria litis, que no puede tener incidencia alguna en la dilucidación del asunto que deberá fallar el tribunal ordinario.

b) El examen de constitucionalidad a que da lugar la sustanciación de una acción de inaplicabilidad debe diferenciarse nítidamente de aquel que motiva la interposición de un amparo extraordinario de garantías constitucionales, como el que existe en otros países a cargo de la justicia constitucional. Del claro tenor literal del número $6^{\circ}$ y del inciso undécimo del artículo 93 de la Constitución se desprende que lo que el constituyente ha perseguido con la configuración de este mecanismo de control represivo concreto de constitucionalidad es impedir que se fallen las cuestiones sometidas a los tribunales ordinarios o especiales en términos que vulneren las disposiciones de la Constitución, por lo cual resulta coherente que entre los requisitos de admisibilidad de la acción se exija que la aplicación del precepto legal impugnado pueda resultar decisiva en la resolución del asunto sublite. No es, en consecuencia, la acción de inaplicabilidad una vía constitucionalmente idónea para cautelar la vigencia de todo tipo de garantías consagradas en la Carta Fundamental, sino sólo de aquéllas cuya vulneración se configure por la aplicación de normas legales que el respectivo sentenciador pueda tener en cuenta al momento de decidir el asunto sobre que recae el ejercicio de la potestad jurisdiccional. Para la tutela de las demás garantías de superior rango estatuidas por nuestro ordenamiento jurídico existen otros medios adecuados, entre ellos, el recurso constitucional de protección, sin dejar de tener en cuenta la labor tuitiva que el propio Tribunal Constitucional puede ejercer respecto de toda garantía constitucional con ocasión del ejercicio de los controles preventivos a su cargo.

Este argumento resulta, en mi concepto, objetable, puesto que de ninguna de las normas constitucionales u orgánico-constitucionales que regulan el ejercicio de la acción de inaplicabilidad (artículo 93 No 6 de la Constitución Política de la República; y artículos $25 \mathrm{C} \mathrm{N}^{\circ}$ s. 6 y 8, y 47 letras B y K de la Ley No 17.997), fluye-conforme su tenor literal- la exigencia de que las normas impugnadas incidan directamente en la resolución de la cuestión pendiente. Más bien, dicha postura doctrinaria pareciera responder a una inadecuada extrapolación de la lógica aplicable a la admisibilidad del recurso de casación ante la Corte Suprema, conforme dispone el artículo 772 del Código de Procedimiento Civil.

\subsubsection{El carácter residual de la impugnación en sede jurisdiccional}

Esta es una de las argumentaciones que se esgrimieron en la STC Rol No 11732009, de 16 de abril de 2009, que desestimó la inconstitucionalidad del solve et repete contenido en el -hasta entonces vigente- artículo 474 inciso tercero del Código del Trabajo ${ }^{33}$. En virtud del principio ahí sentado, no resultarían con-

\footnotetext{
${ }^{33}$ STC Rol No 1173-2009, 16 de abril de 2009, Considerando $13^{\circ}$.
} 
trarias a la Constitución aquellas normas que fijaran la figura en estudio, cuando el ordenamiento jurídico otorgara al afectado la posibilidad de recurrir en sede administrativa contra la multa respectiva, en forma previa al reclamo judicial. En tales casos no estaríamos en presencia de un solve et repete propiamente tal, sino que de uno -conforme expresa el sentenciador constitucional- "mitigado" o "relativizado", y por tanto libre de reproche.

En efecto, el Tribunal razonó en aquella oportunidad lo siguiente:

"DECIMOTERCERO: Que, más allá de las argumentaciones sostenidas por el requirente, debe tenerse presente que estamos en presencia de una especie relativizada y mitigada de la regla solve et repete', pues los artículos 481 y 482 del Código del Trabajo (texto no reformado) facultan al Director del Trabajo a dejar sin efecto las multas a petición del afectado, sin pago previo de las mismas, en un verdadero recurso administrativo no sujeto a erogación alguna. En la práctica y sólo una vez agotada dicha vía, se ejerce la acción del artículo 474 ante los tribunales de justicia, según lo habilita el propio artículo 482 aludido, surgiendo en ese momento la obligación de consignar el tercio de la multa para reclamar".

Dicha argumentación resulta del todo inadecuada, por cuanto es inadmisible la confusión que el considerando citado sugiere entre las órbitas funcionales del órgano administrativo revisor y el de los Tribunales de Justicia. Respecto del primero de ellos, su decisión desfavorable importa un acto esencialmente lesivo del interés particular del administrado, máxime si se considera que el órgano revisor es, a su vez, el cursor de la sanción que se reclama; en el segundo, en cambio, la resolución del conflicto supone -en cuanto ejercicio de la función jurisdiccional- la imparcialidad e impartialidad del órgano decisor. Luego, el solve et repete en estos casos será tan "propiamente tal" (y por tanto reprochable) como en aquellos en que no se prescribe la existencia de una vía administrativa previa a la formulación judicial del reclamo.

\subsubsection{La suspensión de los efectos del acto impugnado durante el juicio de reclamación}

Este argumento -sostenido por los Ministros señores Colombo y Fernández FREDES-, en su voto minoritario de la STC Rol No $1345-2009^{34}$ alude a que, en razón de lo dispuesto por el artículo $3^{\circ}$ inciso final de la Ley No $19.880^{35}$, es procedente desestimar la inconstitucionalidad del solve et repete, por cuanto la

\footnotetext{
${ }^{34}$ Sentencia objeto del capítulo 4 de este estudio, relativa a la declaración de inconstitucionalidad del solve et repete en materia sanitaria.

${ }^{35}$ El cual dispone la excepción al principio de ejecutoriedad del acto administrativo, en virtud de la reclamación del mismo ("Los actos administrativos gozan de una presunción de legalidad, de imperio y exigibilidad frente a sus destinatarios, desde su entrada en vigencia, autorizando su ejecución de oficio por la autoridad administrativa, salvo que mediare una orden de suspensión dispuesta por la autoridad administrativa dentro del procedimiento impugnatorio o por el juez, conociendo por la vía jurisdiccional').
} 
sola posibilidad de que el juez que conoce de una acción de reclamación decrete la suspensión de los efectos de la multa mientras se sustancia el procedimiento respectivo, hace plenamente compatibles a la presunción de legalidad de los actos administrativos con el derecho de acceso a la justicia por parte de los afectados, tornando en improcedente, por tanto, el reproche.

En efecto, los sentenciadores de minoría aludidos estuvieron por rechazar la inconstitucionalidad del solve et repete contenido en el artículo 171 , inciso $1^{\circ}$, frase final, del Código Sanitario, en virtud de los razonamientos expresados en los siguientes considerandos, aquí reproducidos:

"10 Que, tal como lo reconoce la propia sentencia de la que disentimos, en el literal a) de su razonamiento segundo, la trascendencia que para el ordenamiento jurídico reviste la declaración de inconstitucionalidad prevista en el número $7^{\circ}$ del artículo 93 constitucional, exige que la misma sólo tenga lugar cuando el precepto legal reprochado no admita interpretación que lo haga conciliable con la normativa constitucional concernida en el respectivo cotejo de normas.

$2^{\circ}$ Que, en la situación materia de estos autos, el precepto legal cuya inconstitucionalidad declara el voto de mayoría no conculca el derecho de acceso a la justicia de la persona afectada por una resolución sancionatoria de la autoridad sanitaria, toda vez que el propio ordenamiento jurídico contempla la posibilidad de que el reclamante pueda ser liberado de la obligación de pagar la multa que se le ha impuesto antes de que el órgano jurisdiccional respectivo se pronuncie sobre la procedencia de su reclamación.

$3^{\circ}$ En efecto, siguiendo el principio general de hermenéutica legal denominado de interpretación sistemática, cabe concordar lo dispuesto en el inciso primero del artículo 171 del Código Sanitario con lo que, a su turno, preceptúa el inciso final del artículo $3^{\circ}$ de la Ley No 19.880, sobre Bases Generales de los Procedimientos Administrativos, en cuya virtud el sancionado inconforme con la multa impuesta por la autoridad administrativa puede obtener tanto de ésta como del órgano jurisdiccional ante el que plantee su reclamación la orden de suspensión de los efectos del acto impugnado hasta que recaiga una decisión sobre el fondo de su inconformidad. Naturalmente que, para obtener tal suspensión, deberá proveer al juez los necesarios antecedentes justificatorios de la plausibilidad de su pretensión. Esta interpretación concordada de uno y otro precepto legal, además de mantener incólume el principio general de la presunción de legalidad e imperio de los actos administrativos, de significación toral en un Estado de Derecho en cuanto respeta escrupulosamente la separación de funciones de los poderes del Estado, presenta el mérito de relativizar la aparente perentoriedad de la norma que el voto de mayoría considera inconstitucional, haciéndola plenamente compatible con la garantía constitucional del acceso a la justicia y precaviendo el uso abusivo del derecho al reclamo para enervar decisiones administrativas sin fundamento atendible".

La posición adoptada en el voto de minoría comentado no resuelve en absoluto, a mi juicio, la cuestión acerca de la conculcación -por medio del solve et repete- del derecho fundamental al libre e igualitario acceso a la justicia. Esto, por cuanto los sentenciadores aludidos sostienen, por medio de la eventual suspensión de la coactivi- 
dad de la sanción pecuniaria aplicada, un verdadero saneamiento (expost) del vicio de inconstitucionalidad, en circunstancias que, en virtud de la barrera aludida, la garantía fundamental ya se ha vulnerado en términos constitucionalmente inadmisibles.

\subsubsection{El criterio económico como eje de mera inaplicabilidad}

Señalamos al comienzo de esta exposición que, para efectos de sostener -con la solidez requerida ante tal pretensión- la viabilidad teórica de la expulsión del solve et repete de nuestro ordenamiento jurídico, era necesario proponer un estándar de constitucionalidad abstracto, que descartara la legitimidad de su procedencia en toda hipótesis de aplicación ${ }^{36}$. Pues bien, ante semejante desafío he decidido finalizar el presente capítulo analizando una posición doctrinaria que, precisamente, propugna lo contrario: vale decir, la racionalidad (aceptabilidad) del solve et repete bajo ciertas condiciones o requisitos. Me refiero a aquel que condiciona la constitucionalidad de la figura a la capacidad económica del actor en el proceso de reclamación judicial.

El argumento aludido es sostenido por el Ministro señor NAVARro BELTRÁn, en primer lugar, en su prevención realizada en la STC Rol No 546-2006, por el rechazo del solve et repete en la norma en contra del artículo 30 del Decreto Ley No 3.538, que crea la Superintendencia de Valores y Seguros (que exige al afectado la consignación del $25 \%$ de la multa, como requisito de procedencia de la acción judicial de reclamo, con un límite máximo de 500 o 1.000 UF, según se trate de una persona natural o jurídica) en los siguientes términos:

"DECIMOTERCERO: Que, por lo demás, tal como lo ha señalado el Tribunal Constitucional Español, la exigencia de una fianza no vulnera per se el derecho a la tutela efectiva, en tanto ella no resulte prohibitiva o particularmente gravosa, lo que en el caso de autos no se produce, en principio, desde el momento que existe un limite razonable establecido por el propio legislador de 500 UF o 1.000 UF, si se trata de personas naturales o jurídicas, salvo ciertas excepciones en las que existe siempre como tope el máximo legal autorizado; por lo que el reproche de constitucionalidad debe ser revisado de manera casuistica".

Luego, el referido Ministro se manifiesta en términos análogos en su prevención efectuada en la sentencia de inconstitucionalidad del solve et repete en materia sanitaria, STC Rol No 1345-2009, señalando que “...Así, en España se ha indicado que el condicionamiento de la admisión de un recurso dirigido contra un acto declarativo del crédito a la efectiva satisfacción de éste limita la posibilidad de impugnación a quienes tengan disponibilidades para ese pago, imponiendo una indefensión absoluta

\footnotetext{
36 "... el paso de la inaplicabilidad concreta a la inconstitucionalidad abstracta presupone haber agotado, dentro de lo razonablemente previsible, las hipótesis de hecho que caracterizan a la primera" (CEA, José Luis (2007). "Praxis del Control de Constitucionalidad en Chile". En: Jornadas Chilenas de Derecho Público XXXVII, Facultad de Derecho de la Pontificia Universidad Católica de Valparaíso, 8 y 9 de noviembre).
} 
a quienes no se encuentren en esa situación, todo lo cual contravendría el derecho a la tutela efectiva de los jueces y tribunales...".

Pues bien, aceptar el criterio antedicho importaría sostener que, si bien es cierto, el solve et repete podría ser objeto de una declaración erga omnes de inconstitucionalidad respecto de ciertos casos específicos, en que la cuantía del gravamen se tornare insoportable para el reclamante $(v . g r$. casos en que la exigencia de consignación previa alcanza al 100\% de la multa, u otros porcentajes de ésta, sin tope), no lo es menos que dicho instituto podría ser perfectamente legítimo en otros, en que la cuantía del gravamen apareciera como atenuada, dando lugar en ellos, a lo sumo, a declaraciones inter partes de inaplicabilidad, en razón de la mayor o menor precariedad de la posición económica del actor.

En razón de las observaciones que en el siguiente capítulo realizaremos, tomando como base la declaración de inconstitucionalidad del artículo 171, inciso $1^{\circ}$, frase final, del Código Sanitario, intentaremos demostrar -hacia el final de la investigación- lo falaz del criterio recién descrito.

\section{LA INCONSTITUCIONALIDAD DEL SOLVE ET REPETE EN LA JURISPRUDENCIA DEL TRIBUNAL CONSTITUCIONAL}

En el presente capítulo se analizará la declaración de inconstitucionalidad en sede de control abstracto, respecto de la norma contenida -hasta hace pocoen el inciso primero del artículo 171 del Código Sanitario ${ }^{37-38}$. Al respecto, se

\footnotetext{
${ }^{37} \mathrm{El}$ solve et repete en materia sanitaria se contenía en la frase final del artículo 171 del Código Sanitario, en los siguientes términos: "De las sanciones aplicadas por el Servicio Nacional de Salud podrá reclamarse ante la justicia ordinaria civil, dentro de los cinco días hábiles siguientes a la notificación de la sentencia, reclamo que tramitará en forma breve y sumaria. Para dar curso a ellos se exigirá que el infractor acompañe el comprobante de haber pagado la multa".

${ }^{38} \mathrm{La}$ declaración de inconstitucionalidad de dicha norma (8 votos a favor, 2 en contra-Ministros Colombo y Fernández--, y una prevención -Ministro Navarro-) tuvo lugar en una actuación de oficio del Tribunal Constitucional, de 10 de marzo de 2009, la cual tuvo como antecedente 6 sentencias previas, declaratorias de inaplicabilidad de dicha norma, las cuales fueron las siguientes:

a) STC Rol No 792-2007, 3 de enero de 2008: Requerimiento de inaplicabilidad interpuesto por Hernán Pfeifer Frenz y las señoras Paulina Alegría Madrid y Carmen Polanco a razón de las multas dictadas por el ISP (Instituto de Salud Pública) por medio de resolución exenta No 6063, de 4 de agosto de 2006, a raíz de la distribución y comercialización del COROVIT, solución inyectable (con fallas de calidad). La multa antedicha, consistente en 30 y 80 UTM a la Directora Técnica y a la Jefe de Control de Calidad, dio lugar a su reclamación en sede civil (11 $1^{\circ}$ Juzgado Civil de Santiago), a través de juicio sumario Rol No 14980 2006, caratulado "Pfeifer Frenz con Instituto de Salud Pública".

b) STC Rol No 1046-2008, 22 de julio de 2008: Requerimiento de inaplicabilidad interpuesto por Renato Fuentealba Macaya, en representación de la Sociedad Sergio Andrés Concha San Martín y Otro, a razón de las multas dictadas por el Seremi de Salud por medio de resolución exenta No 34.606, de 13 de diciembre de 2007 consistente en 100 UTM y la prohibición de funcionamiento de un restaurante. La multa antedicha dio lugar a su reclamación en sede civil (Segundo Juzgado Civil de Concepción), por no haberse acompañado el comprobante de pago de multa como lo dispone la norma impugnada, no se dio curso a la demanda, reponiendo y apelando en subsidio para ante la Corte de Apelaciones de Concepción (Rol No 293-2008) caratulada "Sergio Concha San Martín y otra con Seremi de Salud Región Bío Bío”.
} 
estudiará el estado de la doctrina del Tribunal Constitucional acerca del carácter de fundamental del derecho al libre e igualitario acceso a la justicia, unido a la eventual admisión de ciertos límites en su ejercicio (forjados desde la colisión de aquél con otras garantías de similar rango). Finalmente, se comentarán los argumentos doctrinarios y jurisprudenciales en que se sostiene la decisión adoptada en la STC Rol No 1345-2009, 25 de mayo de 2009, de modo de plantear, al cierre del presente estudio, un principio general de inconstitucionalidad en la materia.

\subsection{Consideraciones previas: Los derechos fundamentales y los limites a la imposición de condiciones para su ejercicio}

La teoría de los derechos fundamentales reconoce al Estado la posibilidad, dentro del ejercicio de la soberanía, de imponer límites a éstos que entraben su ejercicio absoluto. Dichos límites -en el sentido de restricción ${ }^{39}$ - reconocen la existencia de un contenido constitucionalmente protegido, inviolable y prefijado,

c) STC Rol No 1061-2008, 28 de agosto de 2008: Hernán Pfeifer Frenz y las señoras Paulina Alegría Madrid y Carmen Polanco Lazo requieren inaplicabilidad de la segunda frase del inciso primero del artículo 171 del Código Sanitario en causa caratulada "Pfeifer Frenz, Hernán, y otras con Instituto de Salud Pública", $11^{\circ}$ Juzgado Civil de Santiago, Rol No 7770-2008. La multa es de 30 y 80 UTM, respectivamente, para la Directora Técnica y la Jefa de Control de Calidad.

d) STC Rol No 1253-2008, 27 de enero de 2009: Requerimiento de inaplicabilidad deducido por Arco Arquitectura y Construcción Limitada respecto del inciso primero del artículo 171 del Código Sanitario, en la causa Rol No 3240-2008, caratulada "Arco Arquitectura y Construcción Limitada con Secretaría Regional Ministerial de Salud de Valparaíso" del Tercer Juzgado Civil de Valparaíso. La sentencia no expone la cantidad de UTM a la que, en el caso específico, fue condenada por la Administración del Estado.

e) STC Rol No 1262-2008, 2 de abril de 2009: Requerimiento de inaplicabilidad deducido por la Sociedad de Servicios y Asesorías Swan (Chile) S.A. en la causa sobre acción de reclamación de multa administrativa en juicio sumario que se sigue ante el Decimosexto Juzgado Civil de Santiago, Rol No 26.220-2008, caratulada "Sociedad de Servicios y Asesorías Swan (Chile) S.A. con Secretaría Regional Ministerial de Salud de la Región Metropolitana”. La sentencia no expone la cantidad de UTM a la que, en el caso específico, fue condenada por la Administración del Estado.

f) STC Rol No 1279-2008, 2 de abril de 2009: Requerimiento de inaplicabilidad por inconstitucionalidad de Manuel Enrique Valdés Valdés en su calidad de administrador de la Comunidad Edificio Santiago Centro y en su representación, respecto de la parte final del inciso primero, del artículo 171 del Código Sanitario, en causa Rol No 25623-2008, caratulada "Comunidad Edificio Santiago Centro con Secretaría Regional Ministerial de Salud de la Región Metropolitana y Fisco de Chile”. La sentencia no expone la cantidad de UTM a la que, en el caso específico, fue condenada por la Administración del Estado.

${ }^{39} \mathrm{El}$ concepto de limitación de un derecho puede tener dos connotaciones, significa por una parte la determinación del contenido material del derecho, y por otra, la imposición de restricciones al mismo. La limitación, en el último de los sentidos anotados, está contenida -valga la redundancia- por los límites, en la medida que el acto de limitar un derecho no puede llegar al punto de desnaturalizarlo, transformándolo en otro, o haciendo imposible su reconocimiento y ejercicio, como lo establece el artículo 19 No 26 de la Constitución. (Nogueira Alcalá, Humberto (2005). "Aspectos de una Teoría de los Derechos Fundamentales: La Delimitación, Regulación, Garantías y Limitaciones de los Derechos Fundamentales”. Ius et Praxis, Vol. 11, No 2, p. 20). 
el cual conforma el contenido esencial del derecho ${ }^{40}$. Sobre el particular, nuestra Carta Fundamental reconoce, en el numeral 26 de su artículo 19, la viabilidad de dichos límites, señalando que aquellos no podrán afectar los derechos en su esencia, ni imponer condiciones, tributos o requisitos que impidan su libre ejercicio.

En virtud del principio de reserva legal, es el legislador, y sólo él, el llamado a regular, complementar y limitar el ejercicio de dichos derechos, haciendo compatibles éstos entre sí, junto con otros bienes constitucionalmente protegidos. Es lo que la doctrina reconoce, en relación con la última de las alternativas anotadas, como la teoría de los límites externos de los derechos. Así, la regulación de un derecho por el legislador podría importar el establecimiento de restricciones en algunos elementos que no forman parte del contenido esencial del mismo, las que deben justificarse de acuerdo al principio de proporcionalidad que subyace al texto constitucional $^{41}$.

\subsection{El derecho de acceso a la justicia en cuanto garantía de igual protección de la ley en el ejercicio de sus derechos}

Explicado lo anterior, y ya en el marco del análisis de la sentencia en comento, cabe expresar, como cuestión preliminar, que nuestro Tribunal Constitucional-siguiendo una línea doctrinaria sostenida anteriormente en diversos fallo ${ }^{42}-$ expresa en el considerando octavo que la Constitución -no obstante no ser consagrada expresamente- sí incluye el derecho de acceso a la justicia entre las garantías de igual protección de la ley en el ejercicio de los derechos consagradas en el numeral $3^{\circ}$ de su artículo 19 , por cuanto dicha garantía es uno de los mecanismos que deben contemplar las reglas procesales para garantizar un justo y racional procedimiento, constituyéndose como un supuesto necesario de otras garantías explícitas contempladas en la norma, como el derecho a la defensa jurídica, o al juez natural. Por tanto, sin tal acceso, la protección asegurada en el marco del "debido proceso" simplemente no es posible.

\footnotetext{
${ }^{40}$ Sobre este punto, Parejo Alfonso, Luciano (1981). "El contenido esencial de los derechos fundamentales en la jurisprudencia constitucional; a propósito de la sentencia del Tribunal Constitucional de 8 de abril de 1981". Revista Española de Derecho Constitucional, Vol. 1, No 3, pp. 169 y ss. Disponible en: <http://www. cepc.es/revistas/getData.ashx?MAVqs=-aWQ9MjQ1NjYmaWRIPTEwMzcmdXJsPTYmbmFtZT1SRURD XzAwM18xNjkucGRmJmZpbGU9UkVEQ18wMDNfMTY5LnBkZiZ0YWJsYT1BcnRpY3VsbyZjb250 ZW50PWFwcGxpY2F0aW9uL3BkZg==/> [Consulta: 5 enero 2011].

${ }^{41}$ Nogueira Alcalá (2005), p. 26.

${ }^{42}$ Así, se ha razonado en sentencias STC Rol No 184, 7 de marzo de 1994; Rol No 205, 1 de febrero de 1995; Rol No 389, 28 de octubre de 2010; Rol No 376, 17 de junio de 2003; Rol No 478, 8 de agosto de 2006; Rol No 481, 4 de junio de 2006; Rol No 536, 30 de agosto de 2006; Rol No 546, 17 de noviembre de 2006; Rol No 792, 3 de enero de 2008; Rol No 946, 1 de julio de 2008; Rol No 1046, 22 de julio de 2008; y Roles Nos. 1262 y 1279, 2 de abril de 2009.
} 
En relación con lo expuesto en el apartado anterior, hemos de colegir que, habida consideración que el derecho de acceso a la justicia es -según la doctrina analizada - un derecho fundamental componente de la garantía del artículo 19 No 3 de la Constitución Política de la República, le corresponderá al juez la determinación de un contenido esencial, inviolable en el ejercicio de su regulación legal ${ }^{43}$.

\subsection{Examen al limite legal del mencionado derecho fundamental en la norma del inciso primero del artículo 171 del Código Sanitario}

El Tribunal Constitucional razona sobre los siguientes aspectos relacionados con el pago de la multa, establecido como condición de admisibilidad del reclamo judicial (solve et repete):

\subsubsection{Licitud}

Al respecto, el Tribunal concluye (considerando decimotercero) que la limitación se justifica en una finalidad constitucionalmente lícita, cual es evitar la litigación temeraria (frívola) y puramente dilatoria en el cumplimiento de sanciones administrativas, en atención a que "Tal propósito puede servir para dar mayor vigencia a fines que tienen raigambre constitucional, como son los que las sanciones buscan proteger, en la especie, tipicamente la salud, el sometimiento de la actividad de todos al derecho, la eficacia de la actividad estatal y particularmente de la administración y hasta la existencia de racionalidad y justicia en los procedimientos, pues ello exige un uso racional de los recursos judiciales, a los cuales se opone la litigación frivola o puramente dilatoria".

\subsubsection{Razonabilidad}

Establecida la licitud de la finalidad subyacente al solve et repete en materia sanitaria, el Tribunal se pronuncia, sin embargo, negativamente respecto de la razonabilidad (necesariedad) de la norma en examen en cuanto medio para alcanzar el fin señalado. Lo anterior por las siguientes razones:

i. Porque, de conformidad a lo establecido en el artículo 172 del Código Sanitario, en el procedimiento de reclamo judicial de multa, el ejercicio de la respectiva acción no suspende lo resuelto por la autoridad sanitaria. Por lo tanto -razona el Tribunal- "no es posible convencer que la consignación previa resulte un modo eficaz de evitar el reclamo injustificado o puramente dilatorio de la multa, pues el reclamante

\footnotetext{
43 "El contenido esencial del derecho es un concepto jurídico indeterminado que debe determinarse para cada derecho específico. En última instancia será el Tribunal Constitucional, como intérprete final de la Constitución quien especifique tal contenido esencial que hace reconocible al respectivo derecho" (Nogueira Alcalá (2005), p. 45).
} 
se verá sometido igual a cumplir con la sanción de multa y su litigación-justificada o no- tendrá igualmente por objeto recuperar lo que se ha pagado. La única diferencia es que el pago de la multa, establecido como solve et repete, esto es, como condición de admisibilidad del reclamo judicial, es de pago más seguro que el crédito que emana de una sanción, pero ello en nada ayuda a desincentivar la litigación infundada, pues el mecanismo se aplica por igual a los reclamos fundados y a los infundados". Dicho en otros términos, de no existir el solve et repete en materia sanitaria, la autoridad podría de todos modos proceder al cobro de la multa durante la sustanciación del reclamo judicial, sólo que no asegurando, en aquel escenario, el cumplimiento íntegro y exacto del crédito fiscal; situación diversa, en cambio, a la verificable en presencia de la condición de admisibilidad cuestionada. En razón de lo expuesto, es dable sostener que el requisito del solve et repete, lejos de justificarse, no aparece en este aspecto sino como una herramienta de eficacia anticipada para la recaudación estatal (ya en relación con el total de las multas cursadas -como ocurría con el solve et repete en materia sanitaria-, ya en relación con un porcentaje de éstas -como ocurre en el resto de los casos-).

ii. Porque resulta inexacto el afirmar que el solve et repete impide la litigación frívola, por cuanto el sancionado con capacidad de pago tendrá la misma tentación de litigación frivola si posteriormente puede recuperar el dinero pagado que si puede evitar el pago. Por lo tanto -razona el Tribunal- el mecanismo en comento no logra importar, respecto de la litigación temeraria, un mecanismo de desincentivo para aquellos afectados con buena capacidad económica.

iii. Porque, unido a lo anterior, el derecho ya cuenta con mecanismos suficientes destinados a desincentivar la litigación temeraria. Para estos efectos, el Tribunal realiza una distinción respecto de aquellos instrumentos que discriminan y desincentivan los libelos que carecen de fundamento plausible (calificados como medios idóneos), entre los cuales se cuentan los exámenes de admisibilidad y la condenación en costas; y aquellos que no se reúnen en tal criterio directivo, como la barrera del solve et repete (a éste podríamos agregar la consignación en caso de promoción de incidentes dilatorios en materia civil), por la cual se prescinde de cualquier pronunciamiento jurisdiccional respecto del fondo del asunto, al momento de discriminar entre reclamos fundados e infundados, lo que los hace, a juicio del Tribunal, cuestionables desde la perspectiva de su idoneidad.

\subsubsection{Proporcionalidad}

Conforme se ha razonado en el primer apartado del presente capítulo, es el examen (test) de proporcionalidad de la medida limitativa, el que en definitiva autoriza la imposición legítima de la misma. Al respecto, y en relación con el caso comentado, podemos ver cómo se enfrentan en la disputa constitucional, por un lado, el derecho fundamental de acceso a la justicia y, por otro, el pago de la multa establecido como solve et repete, en cuanto elemento contenedor-eventualmentede otras garantías de similar magnitud. 
Examinemos, en el próximo apartado, cómo razona al respecto nuestro Tribunal Constitucional.

\subsection{Solve et repete y control abstracto de constitucionalidad. Argumentos en que se sostiene de la decisión del Tribunal Constitucional}

Sabemos que la declaración abstracta de inconstitucionalidad importa el declarar que un determinado precepto viola la Carta Fundamental, cualquiera sea su hipótesis de aplicación. La decisión comentada plantea lo expuesto respecto de la norma del inciso $1^{\circ}$ del artículo 171 del Código Sanitario, sobre la base de los siguientes razonamientos:

i. El solve et repete como límite al derecho fundamental de acceso a la justicia constituye, en forma indubitada, una restricción al acceso a la jurisdicción. Dicho derecho se ve limitado legalmente por el pago aludido, en el entendido que éste anidaría otros bienes jurídicos igualmente valiosos desde el punto de vista constitucional, "como no debilitar la presunción de legalidad de actos administrativos sancionadores en un ámbito especialmente delicado para la defensa de la vida y la salud, y evitar la litigación infundada con afanes puramente dilatorios" (considerando duodécimo).

ii. Que no obstante ello, de acuerdo a la doctrina del Tribunal ${ }^{44}$, la presunción de legalidad de los actos administrativos debe resultar congruente con el control del ejercicio de las potestades de los órganos del Estado, las que deben asegurar que los derechos fundamentales sean efectivamente respetados y promovidos.

iii. Que la eficacia e imperio de las resoluciones administrativas (bienes jurídicos protegidos por el inciso $1^{\circ}$ del artículo 171 de Código Sanitario, parte final) dicen relación sólo con su posibilidad efectiva de cumplimiento; en ningún caso con las barreras que se establezcan para reclamar de ellas. Luego, al no oprimir el ejercicio de la acción de reclamación el cumplimiento de la sanción administrativa, en razón de lo dispuesto por el artículo 172 del mencionado cuerpo normativo ${ }^{45}$, no se verifica la proporcionalidad de la medida, en orden a proteger la potencialidad de ejecución coactiva (ejecutoriedad) de la sanción pecuniaria. En suma, se estima que aquélla no resulta constitucionalmente admisible en cuanto requisito de procesabilidad de la acción estudiada ${ }^{46}$, procediendo - por tanto- su derogación del ordenamiento jurídico.

\footnotetext{
${ }^{44}$ Así, en sentencia STC Rol No 1173,16 de abril de 2009.

${ }^{45} \mathrm{El}$ cual, como hemos analizado, dispone que "las sentencias que dicte la autoridad sanitaria podrán cumplirse no obstante encontrarse pendiente la reclamación...”.

${ }^{46} \mathrm{Al}$ respecto, la sentencia en estudio razona, en su Considerando Decimocuarto, que "El imperio de las resoluciones administrativas podría servir como argumento -más o menos convincente, no es del caso examinarlo ahora-para sustentar que el reclamo judicial no suspenda siempre y de pleno derecho el cumplimiento de la sanción; pero ello es enteramente independiente a establecer una barrera que dificulta severamente la capacidad de reclamar judicialmente lo resuelto por la Administración. Como ya se ha explicado, es perfectamente posible
} 
Podemos ver, en razón de lo expuesto, que nuestro Tribunal Constitucional ha declarado la inconstitucionalidad del precepto legal comentado, en razón de que toda limitación al derecho de acceso a la jurisdicción, fundada en la presunción de legalidad del acto administrativo sancionador, resulta inadmisible, por cuanto en caso alguno se ve constreñida, por medio del reclamo judicial, la posibilidad de cumplimiento efectivo de la respectiva sanción por parte de la Administración. Cualquier solución en contrario importa transgredir el contenido esencial del derecho fundamental de acceso a la justicia (como ocurría - hasta su derogación- con la norma del inciso $1^{\circ}$ del artículo 171 del Código Sanitario).

Ahora bien, junto con el razonamiento que efectúa el Tribunal Constitucional al respecto, se podría sostener, asimismo, la poca razonabilidad (y lo paradojal) del hecho que la Administración sólo asegurare el pago exacto e íntegro de la obligación pecuniaria, en el evento del reclamo judicial de la misma por parte del afectado en sede administrativa. Esto por cuanto, de no mediar dicha reclamación, y al desaparecer el solve et repete en cuanto requisito de validez de la acción, a la Administración (esta vez acreedora) sólo le cabría obtener el cumplimiento de la sanción por la vía compulsiva ordinaria.

Lo expuesto en el párrafo anterior aparece del todo atentatorio, máxime si se considera que el único bien jurídico tutelado, ante tal óptica (y como ya se ha tenido oportunidad de concluir), es la eficacia de la recaudación; pasando por alto toda consideración y anteposición del principio de la certeza jurídica. Es por ello que no sorprende que la figura en estudio sea, tal como reconoce el propio Tribunal, repudiada por la jurisprudencia europea ${ }^{47}$, o que cierto sector de la doctrina la califique peyorativamente como un "privilegio o beneficio de la Hacienda"

que la barrera de acceso a la justicia desaparezca y luego se establezcan mecanismos destinados a la eficacia directa de lo resuelto por la Administración, mientras ello se discute por la justicia. En la especie, por lo demás, el artículo 172 del Código Sanitario, ya transcrito, establece que el cumplimiento de lo resuelto por la autoridad sanitaria no se suspende por el reclamo judicial'.

${ }^{47}$ En efecto, en STC Rol No 946-2007, 1 de julio de 2008 (considerandos $22^{\circ}$ y 23), el Tribunal expone el estado actual de la jurisprudencia europea sobre el solve et repete, la cual es concluyente en relación con su repudio. Así, el Tribunal manifiesta lo siguiente:

"VIGÉSIMO SEGUNDO: Que, también desde hace algunas décadas, la jurisprudencia europea abordó la constitucionalidad del privilegio que nos ocupa. Desde luego, debe destacarse que mediante sentencia de 24 de marzo de 1961, la Corte Constitucional de Italia declaró la ilegitimidad constitucional de una norma contenida en la Ley de 20 de marzo de 1865, por estimar que el principio solve et repete infringía los artículos 30, 24 y 113 de la Constitución italiana. Las aludidas normas constitucionales consagran, respectivamente, la igualdad ante la ley (artículo 3o), el libre acceso a la justicia y el derecho a la defensa jurídica (artículo 24) y el derecho a recurrir de los actos de la Administración (artículo 113).

Por su importancia en el tema central de esta sentencia, se transcribirán a continuación las consideraciones formuladas en dicha oportunidad por la Corte Constitucional de Italia:

'La cuestión que constituye el objeto del presente requerimiento ha dado lugar hace un buen tiempo a discusiones $y$ decisiones en la doctrina y jurisprudencia, que han planteado diversos modos de calificar el instituto del solve et repete. La tarea del Tribunal Constitucional no es encuadrarlo en una u otra categoría dogmática, sino sólo determinar si puede considerársele constitucionalmente legítimo respecto a las normas contenidas en los artículos 3, 24 y 113 de la Constitución, tal como lo solicita en su ordenanza el Pretor de Pavía. 
Parece conveniente, en primer lugar, destacar que toda alegación en relación al principio de la normal ejecutoriedad de los actos administrativos no contribuye a la resolución de la cuestión, como la ha planteado por la Administración Financiera, porque ese principio no sería en modo alguno menoscabado o eludido con la desaparición del instituto del solve et repete, ya que en tal caso la Administración podría proceder en vía ejecutiva en contra del contribuyente moroso, cualquiera sea su oposición, ya que el tribunal ordinario nunca ha autorizado a suspender la ejecución de las providencias de la autoridad administrativa. Se puede decir, por el contrario, que la propia existencia de este instituto debilita, en cierto sentido, la eficacia de ese principio, racional y prácticamente. El solve et repete es, sin duda, una medida particularmente enérgica y eficaz para realizar el interés público relativo a la percepción de impuestos y, precisamente por esta razón, fue introducido y se ha conservado durante tanto tiempo en la legislación italiana, a pesar de los diferentes proyectos para su supresión, de iniciativa gubernamental y parlamentaria, y a pesar de haber sido sometido durante gran tiempo a severas criticas por la doctrina y a interpretaciones correctivas y restrictivas por la jurisprudencia, la cual, a su vez, ha excluido la aplicabilidad del mismo instituto cuando la pretensión tributaria resulta, a prima facie, absolutamente infundada.

Todo esto confirma que, incluso independientemente de los principios contenidos en la Constitución, y ya antes de su aprobación, se aprecia una importante evolución en la sensibilidad del medio jurídico, la que debe ser correspondida con la interpretación y aplicación de las normas vigentes: evolución causada precisamente por la excesividad de esa medida, que parece no consentida por los principios informadores de un ordenamiento moderno en cuanto a las relaciones entre el ciudadano y el Estado.

Parece dificil creer que el constituyente haya ignorado un problema tan debatido y, menos aún, que no haya considerado resolverlo implícitamente mediante la formulación de principios generales destinados, en gran parte, precisamente, a regular las relaciones entre los ciudadanos y el Estado, conciliando las necesidades de éste con los derechos de aquéllos, y-en cualquier caso-poniendo las condiciones necesarias para que estos derechos puedan ser hechos valer igualmente por todos.

La imposición del pago total del impuesto, regulado como presupuesto imprescindible para interponer acción judicial dirigida a obtener la tutela del derecho del contribuyente mediante la comprobación judicial de la ilegitimidad del impuesto mismo, es contraria, a juicio de este Tribunal, a todos los principios contenidos en los artículos de la Constitución enunciados en la ordenanza del Pretor.

Es contrario a la norma contenida en el artículo 3, porque es evidente la diferencia de trato que resulta entre el contribuyente que es capaz de pagar inmediatamente la totalidad de impuestos, y el contribuyente que no tiene medios suficientes para realizar el pago, ni puede obtenerlos fácilmente mediante un crédito, entre otras razones, porque incluso en caso de victoria en los tribunales, no obtendría el reembolso de las cantidades abonadas sino con retardo. En el primer caso, entonces, es posible, en consecuencia, en razón de su condición económica, solicitar justicia y obtenerla, siempre que pueda demostrar tener la razón; en el segundo caso, esta facultad es dificil sino imposible, no sólo de hecho, sino que también en base al derecho, conforme al cual es presupuesto procesal exigido por la ley y consistente en el pago de una suma, eventualmente, muy considerable.

Las mismas consideraciones valen para justificar las alegaciones en contra de las normas contenidas en los artículos 24, primer párrafo, y 113 de la Constitución, en las cuales el uso de las palabras todos y ciudadanos tiene la clara intención de reafirmar la igualdad de derecho y de hecho de todos los ciudadanos en cuanto concierne a la posibilidad de requerir y obtener tutela judicial, sea frente a otros privados o frente al Estado u organismos públicos menores.

El Tribunal, por lo tanto, es de la opinión que el instituto del solve et repete es contrario a las normas de la Constitución y que debe ser declarada ilegitima la disposición que lo establezca' (Traducción del abogado señor Cristián Román);

VIGÉSIMO TERCERO: Que el Tribunal Supremo de España, por su parte, a través de su Sala de lo contencioso, marcó una clara evolución hacia el rechazo del privilegio del solve et repete. En efecto, en STS 6743/2000, de 25 de septiembre de 2000, la misma Sala se encarga de ilustrar la evolución de su posición en esta materia al señalar:

'Fundamentos de derecho:

(...) CUARTO.- La jurisprudencia de esta Sala ha tenido ya ocasión de pronunciarse en múltiples ocasiones sobre la regla que hace de la consignación, aval o, claro está, del pago de la cantidad reclamada por la Administración una carga previa para poder recurrir. Hasta el punto de que puede hablarse de una clara evolución, en la que tal privilegio de la Administración se ha contemplado desde su eventual incompatibilidad con los principios y

Revista de Derecho · Escuela de Postgrado No 3, julio 2013

Páginas $95-126$ 
(Chiovenda, Uckmar, Zingali, Garido Falla, Mendizábal) ${ }^{48}$, como un "residuo histórico" propio de un pasado vergonzante de la Administración (Mendizábal) ${ }^{49}$ o simplemente como un "arbitrio absolutista" (Soto Kloss) ${ }^{50}$.

\section{CONCLUSIÓN. HaCia Un PRINCIPIO GENERAL DE INCONSTITUCIONALIDAD DEL SOLVE ET REPETE}

En esta investigación he presentado conceptualmente la figura del solve et repete, he expuesto los argumentos doctrinarios y jurisprudenciales en que podría sostenerse un juicio de legitimidad a su respecto, así como las críticas a los mismos,

derechos de igualdad y no discriminación, en perjuicio de los económicamente débiles, y de tutela judicial efectiva, especialmente después de la Constitución; asi como desde la exigencia del necesario rango normativo para su eventual imposición. (...) En consecuencia, es, en la actualidad, doctrina de esta Sala:

a) La regla 'solve et repete', con independencia del rango normativo en que se establezca, puede resultar contraria a la Constitución si su formulación en términos absolutos-concebida sin excepciones en función de la auténtica posibilidad económica de asumir la carga del previo pago, de la previa consignación o de la garantía requerida-, se traduce en un obstáculo efectivo para el acceso a los Tribunales (Cfr. AATS 31 de mayo de 1996 y 21 de marzo de 1997 y SSTS 2 de julio de 1997 y 16 de diciembre de 1999).

b) En la medida en que el recurso ordinario [de alzada] en vía administrativa constituya un requisito necesario para el acceso a la tutela jurisdiccional, la carga previa, en los términos absolutos, sin excepción, que acaban de señalarse, de la consignación o exigencia de determinada garantía para la interposición de aquel recurso implica una restricción indebida del derecho a la tutela judicial efectiva reconocido en el artículo 24 CE (STS 8 de octubre de 1992).

(...) Por consiguiente, para la exigencia del previo pago, consignación o garantía determinada para la admisibilidad de los recursos, tanto administrativos como judiciales, en los términos en que lo permiten los reiterados derechos y principios constitucionales, hace falta que asi se establezca en Ley formal (SSTS 29 de diciembre de 1986, 20 de enero de 1987). En esta dirección abundan también las siguientes razones: 10) la coordinación del ámbito del principio en vía administrativa y jurisdiccional, pues carecería de sentido la admisión indiscriminada del previo pago en los recursos administrativos que eludiría la fiscalización jurisdiccional por el simple hecho de que las normas reglamentarias obligaran a ello; $2^{\circ}$ ) la necesidad de una interpretación restrictiva del principio 'solve et repete', al carecer de fundamento cientifico y constituir un privilegio de la Administración exorbitante al tener siempre en sus manos, como luego se dirá, la ejecutividad del acto administrativo, salvo en los casos en que se acuerde su suspensión; $y 3^{\circ}$ ) por la discriminación, en perjuicio de los económicamente débiles, y subsiguiente infracción del principio de igualdad, cuya proclamación en nuestro ordenamiento jurídico ofrece múltiples manifestaciones (SSTS 26 de marzo y 9 de junio de 1981 y 3 de marzo de 1983).

d) El principio 'solve et repete' es distinto del principio general de la ejecutividad de los actos administrativos, por virtud del cual la Administración puede ejecutar las liquidaciones giradas, de conformidad con los artículos 56 y 93 y siguientes LRJ y PAC y, en particular, los artículos 33 y siguientes de la LGSS (STS, 29 de junio y $1^{\circ}$ de diciembre de 1987). De tal manera que la privación de un recurso administrativo por el incumplimiento del pago, consignación o garantía determinada es un privilegio adicional, agregado a la normal eficacia del acto en cuanto componente definidor de la actuación administrativa, el cual debe ejecutarse mediante el correspondiente apremio para hacer efectiva la liquidación. Mientras que la exigencia del previo pago, consignación, aval o garantía no es otra cosa que facilidad recaudatoria, elemento disuasor del recurso que repercute en sentido impeditivo en el acceso a la vía jurisdiccional con el derivado alcance de suprimir el control en Derecho y por los Tribunales de la actividad de la Administración conforme establece el artículo 106.1 CE (STS, 3 de enero de 1985 y 25 de noviembre de 1986)".

${ }^{48}$ Citados por Martín Oviedo (1969), pp. 152-153.

${ }^{49}$ Ibíd., p. 162.

${ }^{50}$ Soto KLOSS (2009), p. 539. 
luego he desarrollado un análisis acerca de cómo razonó el Tribunal Constitucional a propósito de la legitimidad de la figura en materia sanitaria. Pues bien, en razón de lo hasta aquí expuesto, me parece consecuente estimar que a partir de la STC Rol No 1345-2009, puede extraerse un principio general de inconstitucionalidad, comprensivo de todas las hipótesis de aplicación del solve et repete vigentes en nuestra legislación, y prescindente de toda condición particular del reclamante en el caso concreto. Esto, por las siguientes consideraciones:

1. Las prerrogativas de ejecutividad y ejecutoriedad de los actos administrativos, emanadas de la presunción de legalidad contemplada en el artículo $3^{\circ}$ de la Ley No 19.880, sobre Bases de los Procedimientos Administrativos, son completamente legítimas y necesarias para el actuar de la administración y la eficacia en la materialización de las políticas públicas, no importando el solve et repete una manifestación directa ni refleja de aquellas franquicias ${ }^{51}$, ni pugnando ellas en caso alguno con la noción de debido proceso (como sostiene, entre otros, el profesor Eduardo Soto Kloss) ${ }^{52}$. Esto, por corresponder las nociones de procedimiento administrativo y proceso jurisdiccional a esferas atributivas distintas, con fines, mecanismos y caracteres diversos; siendo, por otro lado, plenamente aceptable la revisión judicial de las decisiones adoptadas por la Administración, eventualmente lesivas de los derechos de los particulares.

2. Que establecida dicha consideración preliminar, cabe señalar que no resulta lógico ni proporcional, respecto de la relación Estado sancionador-particular, la existencia de un medio anticipado de recaudación sobre la multa cursada, considerando que, no obstante la reclamación judicial, la prerrogativa de ejecutoriedad de la sanción administrativa (entendida ésta como la posibilidad de cumplimiento compulsivo de la misma, una vez afinado el respectivo procedimiento administrativo sancionador) permanece incólume. Dicha circunstancia transforma, por sí misma, en inoficiosa y arbitraria la consignación previa de la multa, como requisito de acceso a la jurisdicción (sea referente a un porcentaje de la misma -por mínimo que sea-, o su total), y plantea ésta de inmediato como una mal entendida extensión del principio de legalidad del acto administrativo.

3. Que desde la teoría constitucional, y conforme hemos tenido oportunidad de concluir, es menester señalar que la colisión producida entre el derecho fundamental de acceso libre e igualitario a la justicia (entendido éste como manifestación de la garantía contenida en el artículo 19 No 3 inciso quinto de la Constitución Política de la República) con otros que indirectamente podrían considerarse de carácter colectivo (como el derecho de acceso a la salud, u otros verificables como consecuencia de la recaudación fiscal), debe resolverse en favor del primero, enten-

\footnotetext{
${ }^{51}$ Ver nota 18.

${ }^{52}$ Ver nota 13.
} 
diendo que la imposición de trabas de carácter pecuniario para su ejercicio importa una conculcación intolerable respecto de su contenido esencial.

4. Que resulta evidente que el criterio expuesto descarta por sí mismo la viabilidad de la noción concreta de ilegitimidad del solve et repete, en que la aceptabilidad de la figura ha de examinarse casuísticamente, en función de la capacidad económica del afectado en el respectivo procedimiento jurisdiccional de reclamo. No resulta sensato -en función de lo razonado- que por esa circunstancia se permita la transgresión de dicho derecho fundamental, puesto que ello, en concordancia con lo concluido anteriormente, importa una transgresión flagrante al principio de igualdad ante la ley (artículo 19 No 2 de la Constitución Política de la República).

Para finalizar la investigación, y como consecuencia lógica de lo hasta aquí sostenido, cabe señalar que ante la manifiesta inconstitucionalidad de la figura del solve et repete, se torna imperativo su pronto destierro de nuestro ordenamiento jurídico, ya por derogación legislativa, ya por futuros requerimientos planteados, ante nuestro Tribunal Constitucional, en sede de control abstracto. 


\section{BiBLIOGRAFÍA CITADA}

Aróstica Maldonado, Iván (1987). "Algunos problemas de Derecho Administrativo Penal”. Revista de Derecho, Universidad de Concepción, No 182.

Bordalí Salamanca, Andrés y Ferrada Bórquez, Juan Carlos (2009). Estudios de Justicia Administrativa. Santiago: Editorial LegalPublishing.

CEA, José Luis (2007). "Praxis del Control de Constitucionalidad en Chile”. En: Jornadas Chilenas de Derecho Público XXXVII, Facultad de Derecho de la Pontificia Universidad Católica de Valparaíso, 8 y 9 de noviembre.

Cordero Vega, Luis (2005). "Entre la deferencia, los estándares de control judicial y los procedimientos administrativos. Comentarios a las sentencias sobre el caso Celco". Revista de Derecho Público, No 67, pp. 443-453.

Cordero Vega, Luis (2009). El control de la administración del Estado. Santiago: Editorial LegalPublishing.

Ferrada Bórquez, Juan Carlos (2007). "Las potestades y privilegios de la Administración Pública en el régimen administrativo chileno". Revista de Derecho (Valdivia), Vol. XX, No 2, pp. 69-94.

García de Enterría, Eduardo y Fernández, Tomás Ramón (1996). Curso de Derecho Administrativo. T. I, Madrid: Editorial Civitas.

Izu BeLloso, Miguel José (1993). "Las garantías del procedimiento administrativo sancionador: Reflexiones sobre los órganos instructores, en la protección jurídica del ciudadano: (procedimiento administrativo y garantía jurisdiccional)”. En: Estudios en homenaje al profesor Jesús González Pérez, Martín-Retortillo Baquer, Lorenzo (Coord.). Vol. 1. Disponible en: <http://webs.ono.com/ mizubel/garantias.pdf.> [Consulta: 4 enero 2011].

Martín Oviedo, José María (1969). "La decadencia de la regla 'solve et repete’ y la doctrina del Consejo de Estado”. Revista de Administración Pública, Madrid, No 20.

Nogueira Alcalá, Humberto (2005). “Aspectos de una Teoría de los Derechos Fundamentales: La Delimitación, Regulación, Garantías y Limitaciones de los Derechos Fundamentales". Ius et Praxis, Vol.11, No 2, pp. 15-64.

Parejo Alfonso, Luciano (1981). "El contenido esencial de los derechos fundamentales en la jurisprudencia constitucional; a propósito de la sentencia del Tribunal Constitucional de 8 de abril de 1981". Revista Española de Derecho Constitucional, Vol. 1, No 3. Disponible en: <http://www.cepc.es/revistas/getData.ashx?MAVqs=-aWQ9MjQ1NjYmaWRIPTEwMzcmdXJsPTYmbmFtZT1SRURDXzAwM18xNjkucGRmJmZpbGU9UkVEQ18wMDNfMTY5 LnBkZiZ0YWJsYT1BcnRpY3VsbyZjb250ZW50PWFwcGxpY2F0aW9uL3BkZg==/> [Consulta: 5 enero 2011].

Ramírez Torrado, María Lourdes (2007). "La sanción administrativa y su diferencia con otras medidas que imponen cargas a los administrados en el contexto 
español”. Revista de Derecho, No 27, Barranquilla. Disponible en: <http:// redalyc.uaemex.mx/pdf/851/85102711.pdf> [Consulta: 5 enero 2011].

Román Cordero, Cristián (2009). "El debido procedimiento administrativo sancionador". Revista de Derecho Público, No 71, pp. 183-214.

Román Cordero, Cristián (2010). "El castigo en el derecho administrativo". Revista de Derecho y Humanidades, No 16, Vol. 1, pp. 155-171.

Soto Kloss, Eduardo (1979/1980). "Derecho Administrativo Penal. Notas para el estudio de la potestad sancionatoria de la Administración”. En: Boletín de Investigaciones, Facultad de Derecho, Pontificia Universidad Católica de Chile, No 44/45.

Sото KLoss, Eduardo (2005). "La potestad sancionadora de la Administración, ¿se adecua a la Constitución?”. En: Sanciones Administrativas y Derechos Fundamentales, Regulación y Nuevo intervencionismo, Conferencias Santo Tomás de Aquino, Santiago.

Soto KLoss, Eduardo (2009). "Solve et repete. Notas sobre un resabio absolutista en el Estado Constitucional de Derecho”. En: Derecho Administrativo. Temas Fundamentales, Santiago: LegalPublishing.

\section{NORMAS CITADAS}

Código Sanitario.

Código del Trabajo.

Código Tributario.

Decreto Ley No 3.538, Ley Orgánica de la Superintendencia de Valores y Seguros, Diario Oficial, 23 de diciembre de 1980.

Ley No 19.989, Aprueba reglamento que fija procedimiento para retención de la devolución del impuesto a la renta por parte de la Tesorería General de la República, Diario Oficial, 19 de noviembre de 2009.

\section{Jurisprudencia Citada}

Tribunal Constitucional, Rol No 38-1986, 8 de septiembre de 1986 (control de constitucionalidad respecto del proyecto de ley orgánica constitucional sobre sistema de inscripciones electorales y servicio electoral).

Tribunal Constitucional, Rol No 43-1987, 24 de febrero de 1987 (control de constitucionalidad respecto del proyecto de ley orgánica constitucional de partidos políticos).

Tribunal Constitucional, Rol No 184-1994, 7 de marzo de 1994 (control de constitucionalidad respecto del proyecto de ley que Modifica las Leyes de Mercado de Valores, Administración de Fondos Mutuos, de Fondos de In- 
versión, de Fondos de Pensiones, de Compañías de Seguros, y otras Materias que indica).

Tribunal Constitucional, Rol No 205-1995, 1 de febrero de 1995 (control de constitucionalidad respecto del proyecto de ley sobre composición, organización y atribuciones de la Corte Suprema y modificaciones a los recursos de queja y de casación).

Tribunal Constitucional, Rol No 376-2003, 17 de junio de 2003 (control de constitucionalidad respecto del proyecto de ley sobre transparencia, límite y control del gasto electoral).

Tribunal Constitucional, Rol No 389-2003, 28 de octubre de 2003 (control de constitucionalidad respecto del proyecto de ley que crea la Unidad de Análisis Financiero y modifica el Código Penal en materia de lavado y blanqueo de activos).

Tribunal Constitucional, Rol No 481-2006, 5 de junio de 2006 (requerimiento de inaplicabilidad respecto de los artículos 250 del Código de Procedimiento Civil, y los artículos 215, 217, 218 inciso segundo, 219 y 221 inciso primero, todos del Código Orgánico de Tribunales, en la causa caratulada "State Street Bank and Trust Company con Inversiones Errázuriz Limitada y otros").

Tribunal Constitucional, Rol No 478-2006, 8 de agosto de 2006 (requerimiento de inaplicabilidad respecto del inciso tercero del artículo 416 del Código Procesal Penal, en la causa Rol No 2257-2006 que se sigue ante la Corte de Apelaciones de Santiago).

Tribunal Constitucional, Rol No 536-2006, 30 de agosto de 2006 (control de constitucionalidad respecto del proyecto de ley que regula el trabajo en régimen de subcontratación, el funcionamiento de las empresas de servicios transitorios y el contrato de trabajo de servicios transitorios).

Tribunal Constitucional, Rol No 546-2006, 17 de noviembre de 2006 (requerimiento de inaplicabilidad por inconstitucionalidad respecto del artículo $30 \mathrm{del}$ Decreto Ley No 3.538, en la causa Rol No 9059-06 seguida ante el 8o Juzgado de Letras en lo Civil de Santiago).

Tribunal Constitucional, Rol No 792-2007, 3 de enero de 2008 (requerimiento de inaplicabilidad respecto de la segunda frase del inciso primero del artículo 171 del Código Sanitario, en los autos caratulados "Pfeifer Frenz con Instituto de Salud Pública”, Rol No 14980-2006, en el 11º Juzgado Civil de Santiago).

Tribunal Constitucional, Rol No 946-2007, 1 de julio de 2008 (requerimiento de inaplicabilidad respecto del inciso tercero del artículo 474 del Código del Trabajo, en la causa Rol No 757-07, caratulada "FM Seguridad S.A. con Dirección Regional del Trabajo”, del $8^{\circ}$ Juzgado de Letras del Trabajo de Santiago).

Tribunal Constitucional, Rol No 968-2007, 10 de julio de 2008 (requerimiento de inaplicabilidad respecto del inciso tercero del artículo 474 del Código del 
Trabajo, en la causa Rol No 806-07, caratulada "Asesoría y Servicio con Dirección del Trabajo", del 50 Juzgado de Letras del Trabajo de Santiago).

Tribunal Constitucional, Rol No 1046-2008, 22 de julio de 2008 (requerimiento de inaplicabilidad respecto de la parte final del inciso primero del artículo 171 del Código Sanitario, en la causa caratulada "Concha San Martín, Sergio Andrés, con Fisco", de la Corte de Apelaciones de Concepción).

Tribunal Constitucional, Rol No 1061-2008, 28 de agosto de 2008 (requerimiento de inaplicabilidad respecto de la segunda frase, del inciso primero, del artículo 171 del Código Sanitario, en causa caratulada "Pfeifer Frenz, Hernán, y otras con Instituto de Salud Pública”, Rol C-7770-2008, del 11º Juzgado Civil de Santiago).

Tribunal Constitucional, Rol No 1253-2008, 27 de enero de 2009 (requerimiento de inaplicabilidad respecto del inciso primero del artículo 171 del Código Sanitario, en la causa Rol No 3240-2008, caratulada "Arco Arquitectura y Construcción Limitada con Secretaría Regional Ministerial de Salud de Valparaíso" del Tercer Juzgado Civil de Valparaíso).

Tribunal Constitucional, Rol No 1262-2008, 2 de abril de 2009 (requerimiento de inaplicabilidad por inconstitucionalidad respecto de la parte final del inciso primero, del artículo 171 del Código Sanitario, en causa Rol No 26.220-2008 del Decimosexto Juzgado Civil de Santiago, caratulada "Sociedad de Servicios y Asesorías SWAN S.A. con Secretaría Regional Ministerial de Salud de la Región Metropolitana”).

Tribunal Constitucional, Rol No 1279-2008, 2 de abril de 2009 (requerimiento de inaplicabilidad por inconstitucionalidad respecto de la parte final del inciso primero, del artículo 171 del Código Sanitario, en causa Rol C-25623-2008, caratulada "Comunidad Edificio Santiago Centro con Secretaría Regional Ministerial de Salud de la Región Metropolitana y Fisco de Chile”, del Segundo Juzgado Civil de Santiago y actualmente en apelación ante la Corte de Apelaciones de Santiago).

Tribunal Constitucional, Rol No 1173-2009, 16 de abril de 2009 (acción de inconstitucionalidad respecto del inciso tercero del artículo 474 del Código del Trabajo, que ya fue declarado inaplicable por este Tribunal Constitucional en sentencias Roles $\mathrm{No}^{\circ}$. 946 y 968, de fechas $1^{\circ}$ y 10 de julio del año 2008, respectivamente).

Tribunal Constitucional, Rol No 1345-2009, 25 de mayo de 2009 (pronunciamiento de oficio sobre la inconstitucionalidad de las expresiones: "Para dar curso a ellos se exigirá que el infractor acompañe el comprobante de haber pagado la multa", contenidas en el inciso primero del artículo 171 del Código Sanitario).

Tribunal Constitucional, Rol No 1411-2009, 7 de septiembre de 2010 (acción de inaplicabilidad por inconstitucionalidad respecto del artículo $1^{\circ}$ de la Ley 
No 19.989, en los autos sobre recurso de protección interpuesto en contra de la Tesorería General de la República).

Tribunal Constitucional, Rol No 1437-2009, 7 de septiembre de 2010 (requerimiento de inaplicabilidad por inconstitucionalidad de Úrsula Cortés Zamora respecto del artículo $1^{\circ}$ de la Ley No 19.989, en los autos Rol No 7833-2009 sobre recurso de protección interpuesto ante la Corte de Apelaciones de Santiago en contra de la Tesorería General de la República).

Tribunal Constitucional, Rol No 1438-2009, 7 de septiembre de 2010 (requerimiento de inaplicabilidad por inconstitucionalidad respecto del artículo $1^{\circ}$ de la Ley No 19.989, en los autos Rol No 7767-2009 sobre recurso de protección interpuesto ante la Corte de Apelaciones de Santiago en contra de la Tesorería General de la República).

Tribunal Constitucional, Rol No 1486-2009, 2 de noviembre de 2010 (requerimiento de inaplicabilidad por inconstitucionalidad respecto del artículo $1^{\circ}$ de la Ley No 19.989 en los autos Rol No 8208-2009 sobre recurso de protección interpuesto ante la Corte de Apelaciones de Santiago en contra de la Tesorería General de la República y el Administrador del Fondo Solidario de Crédito Universitario de la Universidad Católica de la Santísima Concepción).

Tribunal Constitucional, Rol No 1449-2009, 9 de diciembre de 2010 (requerimiento de inaplicabilidad por inconstitucionalidad respecto del artículo $1^{\circ}$ de la Ley No 19.989, en los autos Rol No 8063-2009 sobre recurso de protección deducido ante la Corte de Apelaciones de Santiago en contra de la Tesorería General de la República y del Administrador del Fondo de Crédito Universitario de la Universidad de Chile). 